\title{
Gençlerin Akşam ve Gece Saatlerinde Kentsel Merkezi Alan Kullanım Tercihleri
}

\author{
Merve Güngör ${ }^{1}$ \\ ORCID: 0000-0002-7305-2480
}

\author{
Ezgi Orhan ${ }^{2}$ \\ ORCID: 0000-0002-9124-7812
}

Öz

Akşam ve gece saatlerindeki eğlence amaçlı kullamılan aktivite mekânlarının dă̆ılımı, organizasyonu ve karakteri uygulanan politika ve planların yanı stra kullanıclların tercihlerine göre biçimlenmektedir. Başta genç nüfus olmak üzere, kullanıcıların istek ve talepleri doğrultusunda şekillenen gece aktivitelerinin mekânsal organizasyonu ve karakteri merkezi iş alanlarının gelişiminde ve merkezlerin canlılığında etkili bir role sahiptir. Çalışmanın amacı, gençlerin kent merkezlerini gece saatlerinde kullanımları konusundaki tercihlerini analiz ederek, kentin merkezi iş alanlarının gece peyzajını ortaya çıkarmaktır. Ankara'nın farklı merkezi alanlarındaki gece kullanım tercihlerini belirlemek üzere üniversite düzeyinde öğrenim gören gençlerle yüz yüze anket uygulaması yapılmış, seçilen örneklemde yer alan 250 üniversite öğrencisinin tercihleri araştırılmıştır. Gençlerin eğlence mekânlarının yoğunlaştığı ve çeşitli gece aktivitelerine ev sahipliği yapan kent merkezlerine yönelik kullanıcı profiline göre farklılaşan bir gece algısına sahip oldukları ortaya konmuştur. Kullanıcı profili yanı sıra, her bir merkezi alanın gece aktivitelerine dair farklı avantaj ve dezavantajlara sunmasından dolayı da gençlerin tercihlerinin değiştiği tespit edilmiştir. Çalışmanın sonuçlarından hareketle, gece aktivitelerinin kümelendiği farklı niteliklerdeki kentsel merkezi alanlara dair karar vericiler için politika önerileri geliştirilmiştir.

Anahtar Kelimeler: gece planlaması, eğlence mekânları, kent merkezi, genç kullanıcılar.

\footnotetext{
${ }^{1}$ Yüksek Şehir Plancısı, E-mail: merveegungor@gmail.com

${ }^{2}$ Doç. Dr., Çankaya Üniversitesi, E-mail: ezgiorhan@cankaya.edu.tr

id ealkent (c) Kent Araştırmaları Dergisi (Journal of Urban Studies)

http://idealkentdergisi.com
}

Geliş Tarihi Received Date: 21.12.2020 Kabul Tarihi Accepted Date: 22.04.2021 


\title{
Youth's Preference on the Use of Urban Central Districts in the Evening and Nighttime Hours
}

\author{
Merve Güngör ${ }^{3}$ \\ ORCID: 0000-0002-7305-2480
}

\author{
Ezgi Orhan 4 \\ ORCID: 0000-0002-9124-7812
}

\begin{abstract}
The spatial organization and character of the entertainment activities in the evening and night hours are shaped in line with the preferences of the users as well as the policies and plans. The spatial organization and character of night activities, which are shaped by the taste and demand of users, especially the young population, have an effective role in the development of the central business districts. The aim of the study is to reveal the nightscape of the urban central districts by analyzing night-time preferences of young in city centers. In order to determine the nocturnal use of different central parts of Ankara, a face-to-face questionnaire was applied to 250 university students in the selected sample. It is revealed that young people show differentiations in their night perception on the city centers hosting entertainment venues and various night activities. In addition to the user profile, it is showed that young people associated their preferences to the advantages and disadvantages offered by each central area regarding the night activities. Departing from the results of the study, policy recommendations for decision makers on urban areas hosting differentiating night-time activities.
\end{abstract}

Keywords: night-time planning, entertainment places, city center, young users.

\footnotetext{
${ }^{3}$ City Planner, MSc., E-mail: merveegungor@gmail.com

${ }^{4}$ Assoc. Prof., Çankaya University, E-mail: ezgiorhan@cankaya.edu.tr

idealkent (c) Kent Araştırmaları Dergisi (Journal of Urban Studies) 


\section{Giriş}

Bir kentin merkezinde hava karardıktan sonra gerçekleşen etkinlikler o şehrin imgesini ve yaşanabilirliğini şekillendirmede önemli bir rol oynamaktadır. Ayn zamanda, bu etkinliklerin yerel ekonomi üzerinde de önemli bir etkisi vardır. Gece ekonomisi olarak adlandırılan kavramı Hannigan (1998) gece saatlerindeki sosyalleşme ve eğlence kalıplarıyla ilişkili boş zaman etkinlikleri olarak ifade etmektedir. Daha geniş anlamıla ise gece ekonomisi, gündüz ekonomisinin durduğu 18:00-06:00 saatleri arasında yapılan ekonomik faaliyetleri kapsamaktadır (Seijas, 2018). Gece ekonomisi ve yirmi dört saatlik şehir kavramları dünyada 1990 'l 1 yıllardan itibaren yerel politika yapıcılar tarafından benimsenmiştir. Bu akımla, başta Avrupa ülkelerinde olmak üzere birçok kentte, kentsel yenileme, turizm ve kültürel ekonomiyi kolaylaştırmak için gece hayatı bölgeleri inşa edilmiştir (Matthew ve Chew, 2009). Rowe vd. (2008) en güvenli, en ilginç ve en başarılı şehir merkezlerinin, geceleri terk edilmeyen ve kullanım çeşitliliğini destekleyen merkezler olduğunu savunmaktadır. Kentin merkezi bölgelerinde "hava karardıktan sonra" gerçekleşen etkinliklerin planlaması kentsel canlılığın sürdürülmesini ve yaşanabilirliğini desteklemektedir. Bu nedenle, gece mekânlarının geliştirilmesini ve farklı insan grupları tarafından kullanılmasını sağlamak önemlidir. Türkiye'de ise gece ekonomisinin sosyal, ekonomik ve mekânsal boyutları yerel politika yapıcılar ve plancılar için oldukça yeni bir alandır ve henüz gelişme aşamasındadır.

Türkiye kentlerinde gece ekonomisi, gece aktivitelerinin mekânsal olarak örgütlenmesi ve kent merkezlerinin gece görünümüne dair çalışmalar oldukça sınırlıdır. Kent merkezlerinde yığılan gece ekonomisinin nasıl biçimlediğini göstermek kent merkezlerinin gelişimini anlamaya yardımcı olacaktır. Gece aktivitelerinin mekânsal organizasyonu ve karakterini sergileme yollarından biri kullanıcı tercihlerine yönelmektir. Bu perspektiften yola çıkan yazının amacı, gençlerin kent merkezlerinin gece kullanımları konusundaki tercihlerini analiz ederek, kentin merkezi iş alanlarındaki eğilimleri ortaya çıarmaktır. Gençlerin kent merkezlerini kullanımlarını incelemeye yönelen çalışmada, kentsel mekânları tercih etme nedenleri ve bu tercihlerin kentsel alanları nasıl biçimlendirdikleri araştırılmaktadır. Bu sayede, gençlerin farklı merkezi alanlara dair tercihlerinin, eğlence mekânlarına yönelik eğilimlerin, akşam ve gece saatlerinde kentle olan deneyimlerin ortaya konulması hedeflenmiştir.

Gençlerin eğlence mekânlarının yoğunlaştığı ve çeşitli gece aktivitelerine sahip merkezi iş alanlarına yönelik yaklaşımını ortaya koyan yazıda öncelikle 
kentsel gece zamanına ilişkin literatür taramasına yer verilmiştir. Sonraki bölümde, ampirik bir saha çalışması olarak kurgulanan araştırmanın metodolojisi özetlenmiş ve örnek alan belirlenen Ankara kentinin merkezi alanlarının gelişimi tarihsel bir bakışla sunulmuştur. Saha araştırmasından elde edilen verilerin analizinden hareketle üniversite öğrencilerinin akşam ve gece saatlerinde kent merkezlerine ilişkin değerlendirmeleri ortaya konulmuştur. Bu çıkarımlar doğrultusunda, kent merkezlerinin gece peyzajının bir kesiti alınarak kentsel canlılığın sürdürülmesine yönelik mekânsal politikalar önerilmiştir.

\section{Kentsel Gece Zamanı}

Kentsel merkezi alanlar iş etkinliği yığılmalarının yanı sıra, insanların sosyal ve ticari faaliyetlerini yapabildikleri ve boş vakitlerini geçirdikleri eğlence alanlarını da kapsamaktadır. Tellan (2016), eğlence mekânlarını giyim-kuşam, yiyecek ve içecek, oyun, dans, müzik, spor, tiyatro, sinema, müze, festival, sergi gibi çok farklı ortam ve etkinlikleri içerisinde barındırarak popüler kültürün oluşturulma, dönüştürülme, anlamlandırlma, aktarılma ve ilişkilendirilme sürecinin bir parçası olarak tanımlamıştır.

Kentsel merkezi alanların en dikkat çekici özelliği gece ve gündüz arasındaki farklılıktır. Güzelsoy (2008, s.40) kent merkezlerini "gündüz nüfusunun, etkinliklerin, iletişim ve yüz yüze etkileşimin, alınan kararların, yapılan işlerin, yaratılan değerlerin, ulaşımın, yapılaşmanın ve altyapı ağlarının en yoğun olduğu, kiralar, arazi fiyatları ve vergi gelirlerinin en yüksek olduğu kentsel alanlar; başta ticaret olmak üzere kişisel, mesleki, işsel ve kamusal hizmetler ile depolama ve imalat gibi birçok kullanımın iç içe geçtiği yerler" olarak tanımlamaktadır. Ancak, kent merkezleri yalnızca gündüz saatlerinde faaliyet gösteren iş alanlarını değil, akşam ve gece saatlerinde de çekim yaratan kullanımları barındırmaktadır. Bu kez, kullanımlar çalışma ve iş odağından daha çok boş zaman ve eğlence odağına dönüşmüştür.

20. yüzyıl öncesinde, kentsel merkezler hava karardıktan sonra suçların, gayri resmi işlerin, sapkınlıkların yapıldığı alanlar olarak kabul edilegelmiş ve gece zamanı kaygı ve bilinmezlikle özdeşleştirilen kentsel açık alandan iç mekâna çekilmiştir. 1879 senesinde ampulün keşfedilmesi ile birlikte sokakların bilinmeyen yüzü ve olumsuzlukların yaşandığı karanlık gece dünyası algısı yıkılmaya başlamıştır. 20. yüzyıldan itibaren kentsel alanlarda elektrikli aydınlatmanın genişlemesi ile bugünkü modern gece metropollerinin ilk adımı atılmıştır (Lovatt ve O'Connor, 1995). Gecenin aydınlatılmaya başlatılması ile gece saatlerinde korku algısıyla özdeşleşen merkezi alanlar, tüketim alanı ve eğlence mekânı haline dönüşmeye başlamıştır. 
II. Dünya Savaşı' nın ardından, kent merkezleri, yaşanılan, çalışılan ve eğlenilen yerler olarak yenilenmiştir (Lovatt ve O'Connor, 1995). Kent merkezlerinde güçlü ekonomik ve kültürel üretim sistemleri geliştirilmeye başlanmıştır. Gündüz etkinlikleri perakende ticaret ve uzmanlaşmış iş kollarına odaklanırken, akşam ve gece etkinliklerinde gece kulübü, restoran, sinema, tiyatro, konser salonu gibi kültürel ve eğlence amaçlı faaliyetler yoğunluk göstermektedir (Thomas ve Bromley, 2000). Ancak, 1950lerden itibaren otomobil sahipliliğinin tetiklediği banliyöleşme hareketi kent merkezlerini önemli ölçüde etkilemiştir; gece saatlerinde merkezlerdeki aktivitelerin yoğunluğu azalmaya ve çalışan s1nıfın konut alanına dönmesiyle canlılığın yitiren, sönük bir görünüme bürünmüştür. Gündüz ve gece devinimindeki bu ayrım, 1980 sonrasında yeni üretim biçimleri ve esnek çalışma düzeni ile giderek azalmaya başlamış ve kent merkezleri gece saatlerinde de çalışan nüfusu barındıran alanlar olmaya başlamıştrr. Roberts ve Eldridge (2009), gündüz etkinliklerinin gece saatlerinde de yer bulmasında, aydınlatmanın değil, esnek çalışmanın getirdiği iş ve boş vakit zamanlarının iç içe geçmesinin etkili olduğunu savunmuştur. Bu süreklilik hareketiyle birlikte, gece hayatını eğlenme amaçlı kullananların yanı sıra gece zamanı kullanıcılarına hizmet, sağlık ve ulaşım sunmak ve gece hayatının güvenliğini, korumasını, yönetimini sağlamak için çalışan bir nüfus da eklenmiş, böylece uzmanlaşmış ve kalabalık hizmet sektörü çalışanlarının gece vardiyasına ev sahipliği yapan merkezler canlılık kazanmıştır.

Kentin gece saatlerindeki kullanımlarında en etkin grup gençlerdir. Genç yetişkinlerin, eğlence alanlarını barındıran kentsel merkezi alanların gece saatlerindeki kullanımında etkin olarak yer aldıkları görülmektedir. Öğrenciler ve gençler için gece hayatı eğlencesi başkalarıyla tanışmak, rahatlamak ve eğlenmekle ilgilidir (Liempt vd., 2015). Gece hayatı eğlenceleri gençlerin kimliğinin inşasında önemli bir toplumsal dönüşüm olarak kabul edilmektedir (Cattan ve Vanola, 2013; Chatterton ve Hollands, 2003; Hollands, 1996). Gençlerin ve genç yetişkinlerin "şehri ve kültürü deneyimlemeleri", iletişim ağını genişletmeleri ve yaşam tarzlarını keşfetmeleri için gece hayatı mekânları ve etkinliklerinin önemi yazında vurgulanmaktadır (Thomas, 2000; Cattan ve Vanola, 2014; Chatterton ve Hollands, 2003; Hollands, 1996; Liempt, van Aalst ve Schwanen, 2015). Genç nüfusun bir alt kümesi olan üniversite öğrencilerinin sosyal etkileşim ağları ise üniversite yerleşke alanı ve gündüz saatleri ile sınırlı değildir; aksine, kentsel gece hayatı ortamlarında sosyal etkileşime katıldıkları ve hatta kentsel gece hayatının biçimlenmesinde rol üstlendikleri söylenebilir. Thomas (2000) gece hayatının, öğrencilerin iletişim ağlarını genişletmelerine yardımcı olduğunu ortaya koyan çalışmalardan birini yürütmüştür. Oldenburg (1989) 
ise gençlerin arkadaşları ile birlikte sosyalleşmeleri ve gayri resmi toplumsallaşmaları için barlar, restoranlar, kafeler ve diğer gece hayatı mekânlarının alan sunduğunu göstermiştir.

Türkiye kentleri örneğinde, kentsel merkezi alanların akşam ve gece saatlerinde kullanımı ile ilgili yapılmış akademik çalışma bulunmamaktadır. Bu çalışma, Türkiye'de kentsel merkezlerin akşam ve gece saatlerinde kullanımına yönelik ilk girişimlerden biri olan "Üniversite öğrencilerinin kentsel merkezi alanları akşam ve gece saatlerinde kullanımı: Ankara kenti örneği" başlıklı yüksek lisans tezinin bulgularından bir kısmını sunmaktadır. Tez çalışmasından üretilen bu yazının amacı gençlerin gece saatlerinde eğlence mekânlarını kullanma tercihlerini araştırarak kentin merkezinin yayılımını anlamayı ve farklı nitelikteki iş alanlarının kullanıclar tarafından tercih edilme veya edilmeme sebeplerini belirlemektir. Bu amaç doğrultusunda, kenti akşam ve gece saatlerinde daha sık kullanan genç yaştaki kullanıcı grubunu hedef alan görgül bir araştırma tasarlanmıştır. Araştırma sahası olarak kent merkezindeki değişimlerin izlenebildiği Ankara kentsel merkezi iş alanları belirlenmiştir.

\section{Metodoloji}

Kent merkezlerinin akşam ve gece saatlerindeki kullanımını deneyimleyenler üzerinden incelemeyi hedefleyen araştırma bir saha çalışmasına dayanmaktadır. Çalışmada, Ankara kenti merkezi alanlarının kullanımları incelenmiştir; saha çalışması olarak seçilmesinin nedeni kentin zaman içinde gelişen ve birbirinden farklı niteliklere sahip merkezi alanları barındırmasıdır.

Ankara'nun demografik, sosyal, politik ve ekonomik değişimlere koşut kentsel gelişme eğilimleri ilk imar planlarından bu yana değişim göstermektedir. Lörcher'in (1925) bulvar ve meydanların temelini oluşturan ve Jansen'in (1932) tarihi ve planlı merkezini biçimlendiren planlama kararları ile başkentin çekirdeği kuzey-güney yönelimli bir gelişme göstermiştir. Jansen Planı'nda eğlence aktivitesi, modern kentin yapısal bir elemanı olarak ele alınmış ve kent, kamusal eğlence mekânları sunacak şekilde tasarlanmıştır (Önder, 2012). Modern başkentin inşası sürecinde, Karpiç Lokantası, Anadolu Kulübü ve Ankara Palas gibi eğlence mekânları devlet eliyle teşvik edilerek, kentin en erişilebilir noktası olan Ulus'ta konumlanmıştır (Sumbas, 2013.) Politik merkez olmanın çekimi ve kırdan kente artan göçlerle nüfus artışının yol açţ̆̆ gelişmeyi yönlendirecek Yücel-Uybadin Planı (1957) ile kentin batı yönünde gelişmesinin ilk izleri oluşturulmuş ve Yenişehir'de gelişen planlı merkez korunmuştur. YücelUybadin Planı'nda yeni bir kent merkezi oluşturma öngörüsü bulunmamakta, Ulus ve Kızılay eksenindeki mevcut merkezi alan kurgusu parlamento yapısı 
ile desteklenmektedir (Günay, 2006). Bu dönemde, piyasa eliyle şekillenmeye başlayan eğlence merkezleri yoğun ticaretin yer aldığı çekirdek alanlarda bulunmakla birlikte, kültürel etkinlikler ile eğlence ve dinlence mekânları Ulus'tan Kızılay'a doğru kayma eğilimi göstermiştir (Bayraktar, 2016). 1950 sonrasında Cumhuriyet dönemi ile özdeşleşmiş Karpiç, Süreyya gibi işletmeler kapanmış, Gençlik Parkı, AOÇ gibi açık alan kullanımları kimlik değiştirmiş, sinema salonları kentin çeşitli noktalarında hizmete girmiş, Kavaklıdere-Çankaya doğrultusunda prestijli kullanımlar yerleşmiştir. Yapısal ve kapsamlı planlama yaklaşımıyla üretilen 1990 Nazım Planı ise kentin batı koridoru üzerinde gelişimini benimseyerek bu eksende ulaşım, konut ve çalışma alanı kararları almıs ve kent merkezinin batıdaki yeni gelişme alanlarına uzanmasını desteklemiştir (Şekil 1). Merkezi alanda örgütlenen faaliyetler kentin merkezi dışına taşınma sürecinin en önemli öğelerinden olan alışveriş merkezi yeni iş alanları boyunca ortaya çımış ve kentin yeni tür eğlence mekânları şekillendirmiştir. Böylelikle, geleneksel merkezden uzaklaşan ve orta-üst gelir gruplarının yöneldiği eğlence mekânlarını barındıran bir merkezi alan oluşagelmektedir. Ancak, kentin gelişmesine koşut olarak biçimlenen merkezi iş alanlarının akşam ve gece saatlerinde kullanımlarına, bu alanlardaki işlevlerin yer seçimine, etkinliklerin dağılıma yönelik planlama kararları geliştirilmediği, özellikle artan eğlence mekânlarına dair parçacı kamu politikalarının geliştirilerek konunun planlama çerçevesi içine alınmadığı ve mekânsal politikalar üretilmediği görülmektedir.

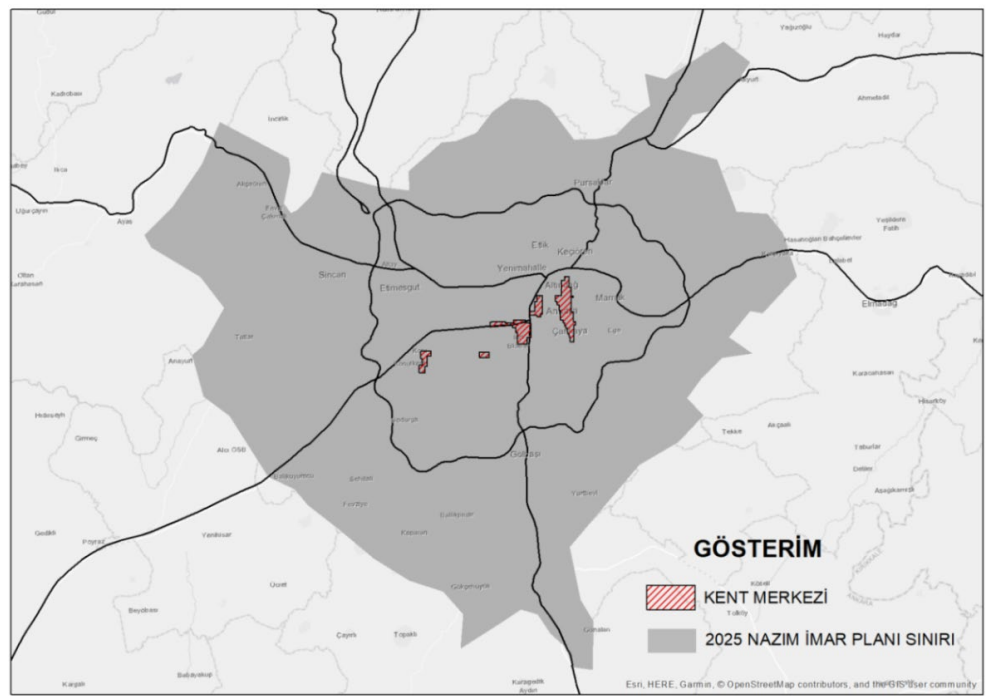

Şekil 1. Ankara 2025 Nazım İmar Planı Sınırı ve çalışmada yer verilen kentsel merkezi alanlar (Kaynak: Güngör, 2020) 
Bahsi geçen ve Ankara planlama tarihinde biçimlenen merkezi alanlara çalışmada üç merkezi alan ve alt alanları olarak yer verilmiş ve tarihi çekirdek, planlı merkez, yeni gelişme koridoru olarak gruplandırılmıştır (Şekil 2).

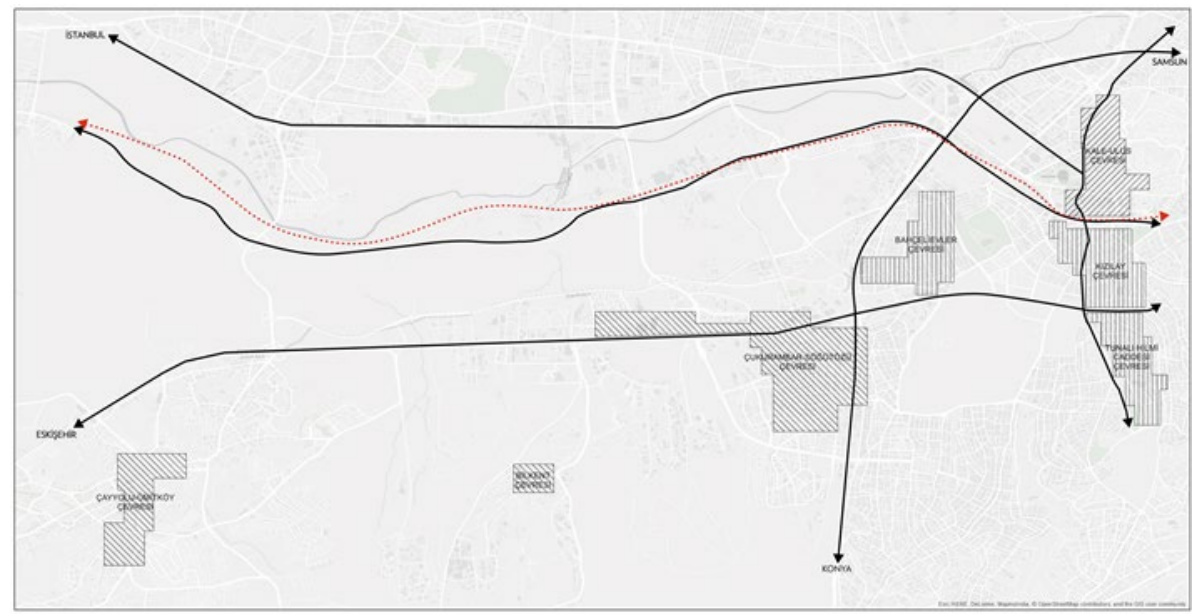

Şekil 2. Çalışmada yer verilen kentsel merkezi alanlar (Kaynak: Güngör, 2020)

Kentin merkezi alanlarındaki farklılaşmanın anlaşılması için kullanıcıların tercihlerindeki farkın ortaya konulması gerekmektedir. Çalışmanın öznesini, gece aktivitelerini ve dağılımlarını biçimlendiren en etken gruplar olan genç nüfus oluşturmaktadır. Bu bakımdan, araştırmada üniversite düzeyinde lisans ve yüksek lisans öğrenimi gören öğrencilerle bir yüz yüze anket uygulaması gerçekleştirilmiştir. Çalışmanın örneklemini bir vakıf üniversitesi olan Çankaya Üniversitesi'nin Ankara'da bulunan her iki yerleşkesinde okumakta olan öğrenciler oluşturmaktadır. Evren büyüklüğü 8800 öğrenci olup, tabakalı rastlantısal örneklem yöntemi ile 250 öğrenci ile anket çalışması yapılmıştır. Tabakalı örneklemde üniversitenin her bir kampüsünde öğrenim gören öğrenci sayısına oranla bir seçim yapılarak; kent merkezindeki Balgat Kampüsü'nde okuyan 120, kent çeperindeki Merkez Kampüs'te okuyan 130 öğrenciye ulaşılmıştır. Örneklemdeki ikinci tabaka ise yaş kriteri olup, 18 yaşın üstündeki gençlere çalışmada yer verilmiştir. Çalışmada belirli bir yaş grubu ve öğrenim düzeyindeki bireylere yer verilmesi, kentin gece hayatının biçimlenişindeki farklı eğlence türlerinin ve gece aktivitelerine vurgu yapılmama olasılığını beraberinde getirmekte olup, bu durum çalışmanın kısıtını oluşturmaktadır. Kentlilerin, günümüzde, genel anlamıla gece aktivitelerine ev sahipliği yapan mekânlar gece kulüpleri, barlar, diskolar, gazinolar, pavyonlar, konser salonları, balo sa- 
lonları, kültür merkezleri, piknik alanları, gezi yerleri, oteller, sinemalar, tiyatrolar, kahvehaneler, nargile salonları, lunaparklar, eğlence merkezleri, alışveriş merkezleri, restoranlar, pastaneler, kafeler ve çay bahçeleri olarak özetlenebilir (Çağlak ve Satır, 2020). Bahsi geçen gece mekânlarından ampirik çalışmanın öznesinin tercihleri gereği yer verilmeyenler bulunmaktadır, ancak kentin gece peyzajını biçimlendirdiği göz ardı edilmemelidir.

Çalışmada kullanılan araştırma materyali üç bölümden oluşan soruları içermektedir; ilk bölümde anketi yanıtlayan kişilerin genel profili, ikinci bölümde ise akşam ve gece saatlerinde kentsel alan kullanımını anlamaya yönelik genç nüfusun tercihleri ve üçüncü bölümde gece saatlerinde merkez kullanımlarına ilişkin değerlendirmeleri sorgulanmıştır. Kapalı uçlu ve yapılandırılmış soruları içeren ankette, öğrencilerin tercihleri 5 noktalı Likert ölçeği ile yanıtlanmıştır. Kullanıcılardan anket ile elde edilen bilgiler tanımlayıc istatistiki veriye dönüştürülmüş ve değişken seti oluşturulmuştur. Buna göre, cinsiyet, öğrenim görülen kampüs, araba sahipliği, Ankara'da ikamet süresi, ikamet türü, akşam saatlerinde kent merkezine çıkma sıklığı, vakit geçirme süresi, dönüş saati ve ortalama harcama tutarına ilişkin veriler bağımsız değişken seti haline getirilmiştir. Kent merkezlerine ilişkin deneyimleri ile bağımsız değişkenler arasındaki ilişki incelenmiştir. Örneklemin kentin hangi bölgelerini tercih ettikleri, bu alanları tercih etme ve etmeme nedenlerine dair öznel değerlendirmeleri analiz edilmiştir. Bu sayede, Ankara kentinin gece peyzajının öğrenciler tarafından nasıl deneyimlendiği ve algılandığı ortaya çıkarılmıştır.

\section{Analiz: Gençlerin gece saatlerinde kentsel merkezi alan kullanımına yönelik tercihleri}

Gençlerin akşam ve gece saatlerinde kent merkezlerini kullanımlarını anlamak için, seçilen örneklemdeki öğrencilerin profili ile merkezi alan tercihleri arasındaki ilişki incelenmiştir. Bu ilişkiyi ortaya koyarken, öncelikle, öğrenciler hakkında bilgi verici nitelikler cinsiyet, öğrenim görülen kampüs, araba sahipliliği, kentteki ikamet süreleri ve ikamet türü olarak belirlenmiştir (Tablo 1). 
Tablo 1. Öğrenci profili ve tanımlayıcı istatistikleri

\begin{tabular}{llll}
\hline Değişken & Gösterge & $\mathbf{N}$ & $\mathbf{\%}$ \\
\hline \multirow{2}{*}{ Cinsiyet } & Kadın & 142 & 56.8 \\
\cline { 2 - 4 } & Erkek & 108 & 43.2 \\
\hline \multirow{2}{*}{ Kampüs } & Merkez & 130 & 52 \\
\cline { 2 - 4 } & Balgat & 120 & 48 \\
\hline \multirow{2}{*}{ Araba Sahipliliği } & Evet & 132 & 52.8 \\
\cline { 2 - 4 } & Hayır & 118 & 47.2 \\
\hline \multirow{2}{*}{ kamet Süresi } & $0-4$ & 31 & 12.4 \\
\cline { 2 - 4 } & $5-19$ & 56 & 22.4 \\
\cline { 2 - 4 } & $20+$ & 163 & 65.2 \\
\hline İkamet Türü & Aile & 200 & 80 \\
\cline { 2 - 4 } & Yurt & 11 & 4.4 \\
\cline { 2 - 4 } & Kendi Dairesi & 39 & 15.6 \\
\hline
\end{tabular}

Buna göre, örneklemdeki öğrencilerin \%34.4'ünün araç sahibi olduğu, yalnızca \%12.4'ünün üniversite öğrenimi süresince Ankara'da ikamet ettiği, \%80'inin ailesi ile yaşadığı anlaşılmaktadır. Ayrıca, ankette verilen yanıtlara göre öğrencilerin \%98.4'ünün bekar, \%97.2'sinin lisans düzeyinde öğrenim gördüğü ve yaş ortalamalarının 22.3 olduğu ortaya konulmuş, bu değişkenler ile araştırmanın geri kalanında bir ilişki aranmadığı için bunlara Tablo 1'de yer verilmemiştir.

Öğrencilerin kentsel merkezi alanları akşam ve gece saatlerinde kullanımlarını anlamak üzere dışarı çıma sıklıkları, vakit geçirme süreleri, kullanılan araç türü, dönüş saatleri ve ortalama harcama tutarları sorulmuştur (Tablo 2). Buna göre, örneklemdeki öğrencilerin akşam ve gece saatlerinde sıklıkla haftada birden çok kez kent merkezini ziyaret ettikleri, dışarıda 4 saat ve üstü vakit geçirdikleri, 22.30 sonrası döndükleri, çoğunlukla özel araçlarını kullandıkları ancak özellikle dönüşte toplu taşıma araçların kullanmadıkları ve ortalama harcama tutarlarının 50-100 TL arası olduğu görülmüştür. 
Tablo 2. Öğrencilerin akşam ve gece saatlerinde kent merkezini ziyaretleri ve kullanma alışkanlıkları

\begin{tabular}{|c|c|c|c|}
\hline \multicolumn{2}{|c|}{ Kent merkezini akşam saatlerinde kullanma alışkanlığı } & \multirow{2}{*}{$\begin{array}{l}\mathbf{N} \\
156\end{array}$} & \multirow{2}{*}{$\begin{array}{l}\% \\
62.4 \\
\end{array}$} \\
\hline Çıkma Sıklığı & Haftada birden çok & & \\
\hline & Haftada bir ve daha az & 94 & 37.6 \\
\hline \multirow[t]{2}{*}{ Vakit Geçirme Süresi } & 4 saat altı & 115 & 46 \\
\hline & 4 saat ve üstü & 135 & 54 \\
\hline \multirow[t]{6}{*}{ Çıkarken kullanılan araç türü } & Yürüyerek/ Bisikletle & 6 & 2.4 \\
\hline & Özel araç & 136 & 54.4 \\
\hline & Taksi & 7 & 2.8 \\
\hline & Dolmuş & 14 & 5.6 \\
\hline & Otobüs & 52 & 20.8 \\
\hline & Metro & 35 & 14.0 \\
\hline \multirow[t]{6}{*}{ Dönüşte kullanılan araç türü } & Yürüyerek/ Bisikletle & 6 & 2.4 \\
\hline & Özel araç & 144 & 57.6 \\
\hline & Taksi & 21 & 8.4 \\
\hline & Dolmuş & 13 & 5.2 \\
\hline & Otobüs & 36 & 14.4 \\
\hline & Metro & 30 & 12.0 \\
\hline \multirow[t]{2}{*}{ Dönüş saati } & 22:30 öncesi & 100 & 40 \\
\hline & 22:30 sonras1 & 150 & 60 \\
\hline \multirow[t]{3}{*}{ Ortalama Harcama Tutarı } & $0-50 \mathrm{TL}$ & 79 & 31.6 \\
\hline & $51-100 \mathrm{TL}$ & 139 & 55.6 \\
\hline & 100 TL ve üstü & 32 & 12.8 \\
\hline
\end{tabular}

Kent merkezlerinde akşam ve gece saatlerindeki deneyimlerine yönelik sorular örneklemdeki üniversite öğrencilerine yöneltilmiştir (Tablo 3). Öğrencilerin, 5 noktalı Likert ölçeğine göre, kendilerine sorulan ifadelere katılıp katılmadıklarına dair bir değerlendirme yapmalan istenmiştir; “5” kesinlikle katılıyorum, "1" ise kesinlikle katılmıyorum ifadesine karşılık gelmektedir. Bu değerlendirmenin sonuçlarına göre, öğrencilerin akşam ve gece saatlerinde kent merkezine gitmekten kaçınmadıkları görülmektedir. Genel değerlendirmeleri açısından, kent merkezlerinin tehlikeli ve güvensiz olduğunu düşünmedikleri fakat güvenlik güçlerinin görünür olmasının güvenlik hissini artırdığını düşündükleri tespit edilmiştir. Akşam ve gece saatlerinde kent merkezlerine tek başına gitmekten kaçınmadıkları, ancak başkasıyla birlikte dışarı çıktıklarında kendilerini daha güvende hissettikleri sonucuna ulaşılmıştır. Yine, öğrencilerin karanlık saatlerde toplu taşıma araçlarını ve taksiyi kullanmaktan kaçınmadıkları fakat kendi araçlarını kullanmalarının daha güvenli olduğunu düşündükleri görülmektedir. Öznel ifadelerine göre kent merkezlerinin akşam ve gece saatlerinde canlılığını yitirdiği, Ankara'da yer alan gece mekânlarının daha çok yerel halkın beklentisine yönelik olduğu ve gece mekânlarının turistleri hedef- 
leyerek düzenlenmediği, sıklıkla gittikleri yerlerin eğlence anlayışlarını yansıttığı, akşam ve gece saatlerinde gece hayatını düzenleyen kararlar alınması gerektiği anlaşılmaktadır.

Tablo 3. Gece saatlerinde kent merkezi deneyimleri (\%)

\begin{tabular}{|c|c|c|c|c|c|}
\hline Gece saatlerinde dışarı çıkma deneyimleri & 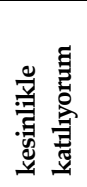 & 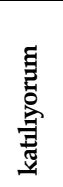 & 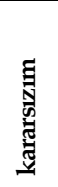 & 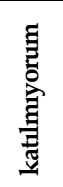 & 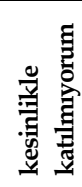 \\
\hline $\begin{array}{l}\text { A. Akşam saatlerinde kent merkezinde } \\
\text { dışarı çıkmaktan kaçınırım. }\end{array}$ & 11.2 & 14.0 & 16.8 & 36.8 & 21.2 \\
\hline $\begin{array}{l}\text { B. Akşam saatlerinde kent merkezinin tehlikeli/ } \\
\text { güvensiz olduğunu düşünürüm. }\end{array}$ & 9.6 & 25.6 & 24.0 & 27.2 & 13.6 \\
\hline $\begin{array}{l}\text { C. Polislerin akşam saatlerinde daha görünür } \\
\text { olması güvenlik hissimi artırır. }\end{array}$ & 22.0 & 33.6 & 21.2 & 13.2 & 10.0 \\
\hline $\begin{array}{l}\text { D. Tek başıma akşam saatlerinde kent } \\
\text { merkezine gitmem. }\end{array}$ & 16.8 & 18.4 & 14.4 & 31.2 & 19.2 \\
\hline $\begin{array}{l}\text { E. Başkalarıyla birlikte olduğumda akşam saatle- } \\
\text { rinde kent merkezinde güvende hissederim. }\end{array}$ & 22.0 & 52.4 & 16.8 & 5.2 & 3.6 \\
\hline $\begin{array}{l}\text { F. Akşam saatlerinde otobüs/dolmuş/metroya } \\
\text { binmekten kaçınurım. }\end{array}$ & 12.4 & 13.6 & 20.8 & 31.6 & 21.6 \\
\hline $\begin{array}{l}\text { G. Akşam saatlerinde taksiye binmekten } \\
\text { kaçınurım. }\end{array}$ & 6.8 & 18.4 & 21.6 & 33.2 & 20.0 \\
\hline $\begin{array}{l}\text { H. Akşam saatlerinde kendi aracımı } \\
\text { kullanmaktan kaçınırım. }\end{array}$ & 2.8 & 4.0 & 12.4 & 22.0 & 58.8 \\
\hline $\begin{array}{l}\text { I. Ankara'da kent merkezi akşam } \\
\text { saatlerinde canlılığını yitirir. }\end{array}$ & 15.6 & 28.0 & 24.8 & 22.4 & 9.2 \\
\hline $\begin{array}{l}\text { J. Akşam saatlerinde kullandığım alanların } \\
\text { yeterli aydınlatılmadığını düşünürü̈m. }\end{array}$ & 10.8 & 30.4 & 27.6 & 22.8 & 8.4 \\
\hline $\begin{array}{l}\text { K. Ankara'nın gece mekânları daha çok turistleri } \\
\text { hedefler; yerel halkın beklentisine yönelik } \\
\text { değildir. }\end{array}$ & 7.2 & 12.0 & 20.8 & 34.8 & 25.2 \\
\hline $\begin{array}{l}\text { L. Gece hayatını düzenleyen kararlar } \\
\text { alınmalı/denetimler yapılmalıdır. }\end{array}$ & 33.6 & 44.0 & 14.4 & 5.2 & 2.8 \\
\hline $\begin{array}{l}\text { M. Akşam saatlerinde sıklıkla gittiğim yerlerin } \\
\text { eğlence anlayışımı yansıttığını ve örtüştüğünü } \\
\text { düşünürüm. }\end{array}$ & 19.6 & 38.8 & 27.6 & 10.8 & 3.2 \\
\hline
\end{tabular}

Gece saatlerindeki deneyimlerine ilişkin sorgulama öğrenci profili ve kenti kullanma alışkanlığını gösteren her bir bağımsız değişken için ortalama değere göre incelenmiştir. Tablo 3'te yer alan ifadeler harfler ile kodlanmış ve tüm kullanıcı gruplarının 5 üzerinden yaptıkları değerlendirmelerin ortalama değerleri Tablo 4'te sunulmuştur. 
Tablo 4. Kullanıc profiline göre gece saatlerinde kent merkezi deneyimlerine dair değerlendirmeler (ortalama-m)

\begin{tabular}{|c|c|c|c|c|c|c|c|c|c|c|c|c|c|}
\hline Değişkenler & $\mathbf{A}$ & B & $\mathrm{C}$ & $\mathbf{D}$ & $\mathrm{E}$ & $\mathbf{F}$ & G & $\mathbf{H}$ & I & $\mathrm{J}$ & $\mathbf{K}$ & L & $\mathbf{M}$ \\
\hline Erkek & $\stackrel{20}{\pi}$ & 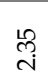 & लె & ले & $\underset{\stackrel{N}{N}}{\stackrel{+}{0}}$ & $\stackrel{\widetilde{I}}{\pi}$ & तิ & กิ & ले & ণ̊ & $\stackrel{\text { If }}{\text { S }}$ & $\begin{array}{l}\bar{\sigma} \\
\end{array}$ & $\underset{\text { ते }}{\mathbb{N}}$ \\
\hline Kadın & $\begin{array}{l}\text { Dे } \\
\text { ì }\end{array}$ & $\stackrel{\vec{\oplus}}{\vec{c}}$ & $\begin{array}{l}\text { 巾े } \\
\text { ले }\end{array}$ & $\stackrel{10}{\oplus}$ & ๙ু & $\stackrel{8}{\infty}$ & ָ̊ & $\underset{\sim}{\stackrel{\varpi}{~}}$ & $\stackrel{8}{\infty}$ & $\stackrel{\nexists}{\pi}$ & $\stackrel{\infty}{\tilde{i}}$ & $\stackrel{\infty}{+}$ & $\stackrel{8}{\circ}$ \\
\hline Balgat Kampüsü & $\underset{\text { i }}{\text { in }}$ & $\begin{array}{l}\stackrel{\leftrightarrow}{n} \\
\stackrel{n}{n}\end{array}$ & ले & $\begin{array}{l}\vec{\infty} \\
\stackrel{N}{N}\end{array}$ & $\begin{array}{l}\infty \\
\infty \\
0\end{array}$ & $\stackrel{\infty}{\stackrel{\infty}{N}}$ & $\begin{array}{l}\stackrel{\infty}{\hat{N}} \\
\text { no }\end{array}$ & $\stackrel{\infty}{\sim}$ & ๙ָ & $\stackrel{\sigma}{\sigma}$ & 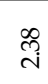 & $\stackrel{\infty}{\stackrel{\leftrightarrow}{~}}$ & $\begin{array}{l}\vec{n} \\
\text { ले }\end{array}$ \\
\hline Merkez Kampüs & กิ & సี & గి & 茫 & $\begin{array}{l}18 \\
0 \\
0\end{array}$ & ֻึ & $\underset{7}{7}$ & 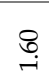 & Fै & तु & $\underset{\mathrm{J}}{\mathrm{J}}$ & $\underset{+}{\sigma}$ & $\underset{m}{R}$ \\
\hline Arabası yok & 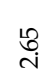 & $\underset{\substack{0 \\
i}}{0}$ & 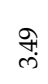 & $\underset{8}{8}$ & $\underset{+}{\infty}$ & $\underset{\vec{d}}{\stackrel{\sigma}{0}}$ & 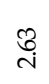 & $\stackrel{\stackrel{2}{\sim}}{\rightarrow}$ & $\stackrel{8}{8}$ & $\underset{m}{\mathscr{m}}$ & น̊ & $\underset{+}{8}$ & तn \\
\hline Arabası var & ڤ్గ & ホু & $\begin{array}{l}\stackrel{9}{9} \\
\dot{m}\end{array}$ & $\begin{array}{l}\text { む্ } \\
\text { d }\end{array}$ & $\begin{array}{l}\widetilde{\sigma} \\
\text { ळi }\end{array}$ & 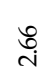 & $\begin{array}{l}\stackrel{L}{R} \\
\stackrel{N}{N}\end{array}$ & 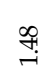 & $\stackrel{m}{\oplus}$ & $\vec{m}$ & సิ & $\begin{array}{l}\infty \\
\dot{m}\end{array}$ & $\stackrel{R}{\stackrel{R}{m}}$ \\
\hline $\begin{array}{l}4 \text { yil ve üstü } \\
\text { ikamet }\end{array}$ & 유 & $\begin{array}{l}\infty \\
\text { id }\end{array}$ & ले & $\underset{\text { d }}{+}$ & $\stackrel{\vec{D}}{\stackrel{+}{0}}$ & di & $\underset{\vec{d}}{\vec{d}}$ & $\stackrel{\Re}{R}$ & तె & $\stackrel{\approx}{\ddot{m}}$ & ন্] & $\underset{+}{\stackrel{8}{ }}$ & $\stackrel{\overbrace{}}{\oplus}$ \\
\hline 4 yll ve alth ikamet & ثิ & ণ্ & $\begin{array}{l}\text { ले } \\
\text { (2) }\end{array}$ & તิ & $\begin{array}{l}\infty \\
\infty \\
\dot{c}\end{array}$ & $\begin{array}{l}\infty \\
\stackrel{\leftrightarrow}{n} \\
\text { no }\end{array}$ & సี & $\underset{\sim}{\Gamma}$ & $\stackrel{8}{\circ}$ & $\underset{\ddot{m}}{\ddot{m}}$ & $\stackrel{\text { S? }}{\text { S }}$ & $\underset{+}{\stackrel{f}{+}}$ & $\stackrel{\text { f }}{\text { ले }}$ \\
\hline $\begin{array}{l}\text { Aile veya } \\
\text { kendi evi }\end{array}$ & స్రి & $\underset{i}{\infty}$ & $\underset{\oplus}{F}$ & ס & $\begin{array}{l}10 \\
\infty \\
\infty\end{array}$ & む্ & i & $\stackrel{\infty}{\stackrel{\infty}{r}}$ & 궁 & $\underset{m}{\ddot{m}}$ & I & $\underset{+}{\sigma}$ & $\underset{\text { तु }}{\text { ते }}$ \\
\hline Yurtta ikamet & $\begin{array}{l}\text { तु } \\
\text { ते }\end{array}$ & तิ & $\underset{+}{\stackrel{8}{+}}$ & $\underset{0}{8}$ & ثु & $\begin{array}{l}\stackrel{L}{R} \\
\text { N }\end{array}$ & లె & $\stackrel{\infty}{\vec{i}}$ & $\begin{array}{l}\stackrel{R}{10} \\
\text { ஸे }\end{array}$ & ๙ิ & તิ & $\stackrel{\sim}{\infty}$ & लె \\
\hline $\begin{array}{l}\text { Haftada birden } \\
\text { az çımaa }\end{array}$ & 今̊ & ๙ু & ?ִ & $\vec{\sigma}$ & $\begin{array}{l}\stackrel{\infty}{\stackrel{0}{m}}\end{array}$ & $\overrightarrow{\mathrm{i}}$ & તิ & $\stackrel{\leftrightarrow}{\stackrel{-}{-}}$ & $\stackrel{\widetilde{T}}{\ddot{\oplus}}$ & $\underset{\infty}{8}$ & గై & $\underset{+}{\infty}$ & $\stackrel{8}{\oplus}$ \\
\hline $\begin{array}{l}\text { Haftada birden } \\
\text { çok çıkma }\end{array}$ & 료 & $\stackrel{\stackrel{N}{N}}{\hat{N}}$ & $\underset{\text { S }}{\mathbb{H}}$ & તิ & $\begin{array}{l}\infty \\
\infty \\
\infty\end{array}$ & ర్ర & గ్ర & $\stackrel{\infty}{\stackrel{\infty}{\leftrightarrow}}$ & సี & $\underset{m}{\ddot{m}}$ & $\underset{\mathrm{J}}{\mathrm{J}}$ & $\begin{array}{l}\stackrel{\vec{m}}{ }\end{array}$ & $\stackrel{8}{\circ}$ \\
\hline $\begin{array}{l}4 \text { saat ve alt } \\
\text { vakit }\end{array}$ & $\begin{array}{l}\widetilde{D} \\
\text { id }\end{array}$ & $\underset{\rho}{8}$ & $\begin{array}{l}R \\
\text { m }\end{array}$ & $\begin{array}{l}\infty \\
\text { i }\end{array}$ & $\begin{array}{l}\infty \\
\stackrel{\infty}{\circ}\end{array}$ & 솟 & 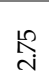 & $\stackrel{\infty}{\stackrel{\infty}{\sim}}$ & $\underset{c}{\stackrel{7}{c}}$ & तె & in & $\stackrel{M}{+}$ & ஸें \\
\hline $\begin{array}{l}4 \text { saat ve üstï } \\
\text { vakit }\end{array}$ & లి & 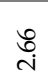 & $\begin{array}{l}\ddot{n} \\
\ddot{n}\end{array}$ & તิ & $\underset{\mathrm{N}}{\mathrm{N}}$ & దิ & $\stackrel{\text { Pִ }}{\mathrm{N}}$ & 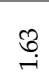 & $\begin{array}{l}\mathbb{N} \\
\text { त }\end{array}$ & $\underset{\dot{\theta}}{8}$ & 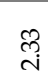 & 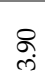 & 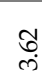 \\
\hline $\begin{array}{l}\text { 22:30dan önce } \\
\text { dönüş }\end{array}$ & ఫे & ते & $\underset{\infty}{\Gamma}$ & ले & $\begin{array}{c}\hat{\infty} \\
\dot{c}\end{array}$ & $\stackrel{\infty}{\infty}$ & $\vec{d}$ & $\stackrel{\infty}{\stackrel{\infty}{+}}$ & $\stackrel{\infty}{\infty}$ & జี & $\stackrel{\mathscr{L}}{\mathrm{N}}$ & $\underset{+}{F}$ & مि \\
\hline $\begin{array}{l}\text { 22:30dan sonra } \\
\text { dönüş̧ }\end{array}$ & ભु & $\stackrel{\sqrt[\vec{n}]{n}}{\sim}$ & సે & $\sqrt[\vec{n}]{\mathrm{n}}$ & $\underset{\infty}{\infty}$ & $\overrightarrow{\stackrel{\vec{n}}{\mathrm{~N}}}$ & $\underset{i}{\mathrm{H}}$ & $\stackrel{\infty}{\stackrel{\infty}{\longrightarrow}}$ & 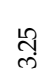 & $\underset{\dot{m}}{8}$ & $\widetilde{\widetilde{N}}$ & $\stackrel{\mathscr{m}}{\stackrel{m}{ }}$ & $\stackrel{8}{\oplus}$ \\
\hline $\begin{array}{l}50 \mathrm{TL} \text { üstü } \\
\text { harcama }\end{array}$ & în & 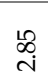 & f & ثิ & $\begin{array}{l}\stackrel{\infty}{\infty} \\
m\end{array}$ & $\vec{\infty}$ & $\begin{array}{l}\text { S్ } \\
\text { în }\end{array}$ & فํ. & $\underset{r}{\vec{c}}$ & $\underset{m}{\vec{m}}$ & సి & $\underset{+}{\sigma}$ & $\stackrel{+}{\stackrel{N}{n}}$ \\
\hline $\begin{array}{l}50 \mathrm{TL} \text { alt } \\
\text { harcama }\end{array}$ & గ̂n & $\stackrel{\overbrace{}}{\stackrel{\overbrace{}}{N}}$ & ले & $\underset{\infty}{8}$ & ஷे & તે & กิ & $\stackrel{N}{\stackrel{N}{*}}$ & 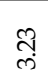 & $\stackrel{10}{\oplus}$ & ત્ & बे & $\stackrel{m}{m}$ \\
\hline $\begin{array}{l}\text { Ortalama } \\
\text { değer (m) }\end{array}$ & م્ & 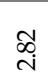 & $\underset{\oplus}{\mathbb{H}}$ & ָิ & 岕 & ה్ & దู่ & $\stackrel{R}{R}$ & $\stackrel{\infty}{\infty}$ & लै & F্ & $\underset{+}{8}$ & $\underset{\sim}{\vec{\omega}}$ \\
\hline
\end{tabular}


Kent merkezlerini akşam ve gece saatlerindeki deneyimlerine dair, kadın kullanıcıların erkek kullanıcılardan farklı olarak kent merkezlerini tehlikeli ve güvensiz olarak gördükleri, güvenlik güçlerinin görünür olmasının güvenlik hissini artırdığını düşündükleri, tek başına kent merkezine gitmekten, gece saatlerinde toplu taşıma veya taksiye binmekten kaçındıkları tespit edilmiştir. Örneklemin gece saatleri deneyimine ilişkin kampüs değişkenine göre yanttlarına bakıldığında Balgat Kampüsü öğrencilerinin Merkez Kampüs'tekilere kıyasla kent merkezlerini daha güvensiz buldukları görülmektedir. Araba sahipliliğine göre kullanıcıların kentsel merkezleri akşam ve gece saatlerindeki deneyimlerine yönelik verdikleri yantlar incelendiğinde, araba sahibi olmayan kullanıcılar arabası olanlara göre, özellikle tek başına akşam saatlerinde çımaktan kaçınmakta ve başkalarıyla birlikte olduklarında daha güvenli hissettiklerini belirtmiştir. İkamet süresi değişkeni açısından incelendiğinde, 4 yıldan daha az süredir Ankara' da yaşayanlar üniversite öğrenimi öncesinde de kentte ikamet edenlere kıyasla, akşam saatlerinde dışarı çıkmaktan kaçınmakta ve güvenlik güçlerinin daha görünür olmasını tercih etmektedir. İkamet yerine göre ise, yurtta kalan öğrenciler diğerlerine göre akşam saatlerinde güvenlik güçlerinin görünür olmasını ve başkalarıyla birlikte çıkmayı tercih etmektedir. Aynı zamanda, yurtta kalan öğrenciler merkezin akşam saatlerinde canlılığını yitirdiğini ve merkezin iyi aydınlatılmadığını düşünmektedir. Daha seyrek çıkanlar haftada bir geceden çok dişarı çıkanlara kıyasla tek başına merkeze gitmekten daha çok çekinmektedir. Dışarı çıktığında daha kısa süre kalanlar ise 4 saat ve üzerinde vakit geçirenlere göre akşam saatlerinde çımaktan çekindiklerini, merkezleri güvensiz bulduklarını ve polislerin olmasının güvenlik hislerini artırdığını belirtmişlerdir. Daha geç saatlerde dönenlere kıyasla, 22.30 öncesi dönenler kent merkezlerine akşam saatlerine gitmekten çekinmekte, daha tehlikeli görmekte, polislerin daha görünür olmasını tercih etmekte, toplu taşıma ve taksiye binmekten kaçınmaktadır. Gece saatlerindeki ortalama harcama tutarına göre öğrencilerin yanıtlarına bakıldığında, daha çok harcama yapanların toplu taşıma kullanmaktan kaçndıkları görülmüştür.

Bu sorgulama, öğrencilerin kent merkezlerine dair farklılaşan bir gece alg1sının olduğunu ve bu farklılaşmanın kullanıc profiliyle ilişkili olduğunu göstermektedir. Bu analizle birlikte kent merkezi deneyimlerinin değişkenlik gösterdiğinin ortaya konulmasının ardından, öğrencilerin akşam saatlerinde kentin hangi alanlarını kullandıkları, kent merkezleri arasında nasıl bir tercih yaptıkları ve gitmeyi tercih ettikleri ve etmedikleri merkezi alanları nasıl algıladıkları, böylece gençlerin perspektifinden kentin gece saatlerinde nasıl görüldüğü 
betimlenmiştir. Bunun için ilk olarak, örnekleme, çalışma için önceden belirlenmiş merkezi alanlardan hangisini hangi sıklıkla kullandıkları sorulduğunda, öğrencilerin başta Çukurambar-Söğütözü Bölgesi (\%28) olmak üzere kentin yeni merkezi iş alanlarını sıklıkla kullandıkları görülmüştür (Tablo 5). Planlı kent merkezini oluşturan alt bölgeler arasında gece saatlerinde dengeli bir ziyaret dağılımı olduğu, ancak geleneksel kent merkezinin örneklemdeki gençler tarafından tercih edilmediği görülmektedir.

Tablo 5. Öğrencilerin akşam ve gece saatlerinde tercih ettikleri kent merkezlerinin dağılımı

\begin{tabular}{|c|c|c|c|c|}
\hline \multicolumn{2}{|c|}{ Akşam ve gece saatlerinde gidilen bölgeler } & \multirow{2}{*}{$\begin{array}{l}\mathbf{N} \\
2 \\
\end{array}$} & \multirow{2}{*}{$\begin{array}{l}\% \\
0.8 \\
\end{array}$} & \multirow{2}{*}{$\begin{array}{l}\text { Toplam \% } \\
0.8\end{array}$} \\
\hline Geleneksel kent merkezi & Kale ve Ulus Bölgesi & & & \\
\hline \multirow[t]{3}{*}{ Planlı kent merkezi } & Kızılay Bölgesi & 40 & 16.0 & \multirow[t]{3}{*}{46.4} \\
\hline & Bahçelievler Bölgesi & 41 & 16.4 & \\
\hline & Tunalı Bölgesi & 35 & 14.0 & \\
\hline \multirow{3}{*}{$\begin{array}{l}\text { Yeni } \\
\text { merkezi } \\
\text { iş alanı }\end{array}$} & Çukurambar-Söğütözü Bölgesi & 70 & 28.0 & \multirow[t]{3}{*}{48.8} \\
\hline & Bilkent Bölgesi & 13 & 5.2 & \\
\hline & Ümitköy-Çayyolu Bölgesi & 39 & 15.6 & \\
\hline Diğer & & 10 & 4.0 & 4.0 \\
\hline Toplam & & 250 & 100.0 & 100.0 \\
\hline
\end{tabular}

Öğrencilerin akşam ve gece saatlerinde kent merkezlerini hangi sıklıkla tercih ettiklerini gösteren dağılım haritasına Şekil 3'de yer verilmiştir. Bu haritadan da görüldüğü üzere en fazla tercih edilen kent merkezi Çukurambar-Sögütözü bölgesi iken geleneksel kent merkezi öğrenciler tarafından tercih edilmemektedir.

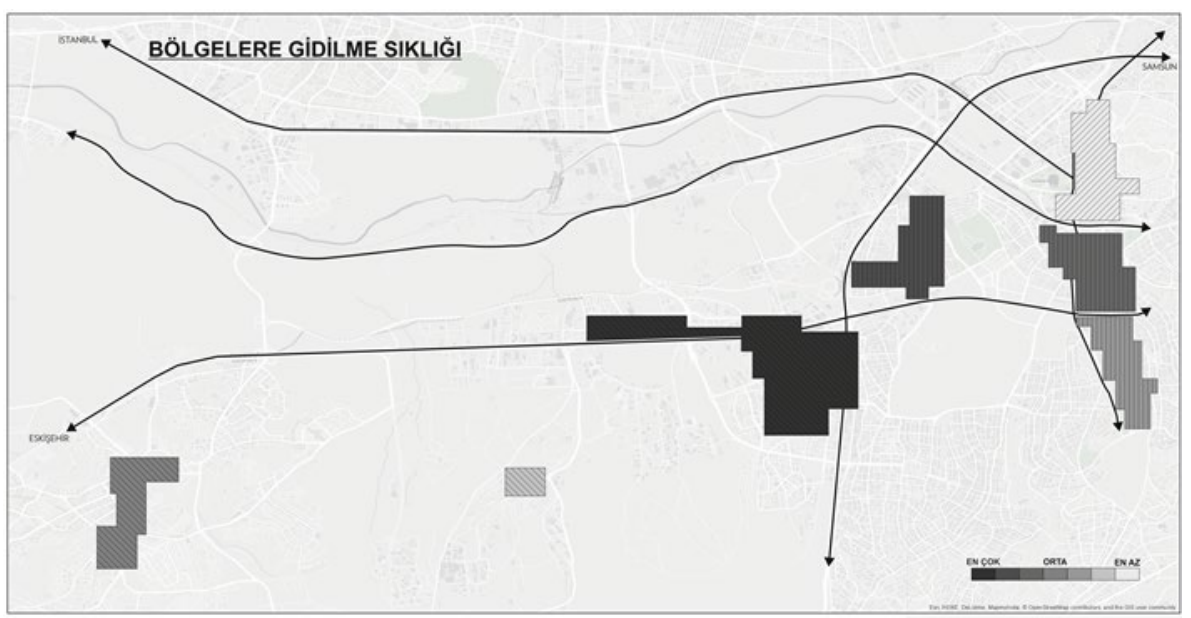

Şekil 3. Öğrencilerin akşam ve gece saatlerinde kent merkezlerini tercih etme sıklıklarının dağılım haritası (Kaynak: Güngör, 2020) 
Gece saatlerinde gençlerin ziyaret sıklıklarında farklılıklar gösterdikleri her bir merkezi alan için tercih edilmelerindeki nedenler sorgulanmış ve Tablo 6' da özetlenmiştir. Alt bölge düzeyinde verilen yantlar incelendiğinde, gece saatlerinde sınırlı sayıda kullanıcısı olduğu anlaşlan Kale ve Ulus bölgesinin tercih edilme nedenlerinin başında ilgi çeken gece mekânlarının/etkinliklerin (\%16.7) ve yeterli ulaşım araçlarının (\%16.7) olması gelmektedir. Kentin planlı çekirdeği olan Kızılay bölgesinin en çok belirtilen tercih edilme nedenlerinin yeterli ulaşım araçlarının olması (\%21.2), ilgi çeken gece mekânlarının aktivitelerin olması (\%16.1), bütçeye uygun mekânların/aktivitelerin bulunması (\%14.8) ve ç1kış-dönüş noktalarına yakın olması (\%14.3) ile ilişkili olduğu görülmüştür. Bu sonuçlardan, kentin diğer bölgelerine doğrudan ulaşım imkânı sunan Kızılay bölgesinin erişilebilirlik nedeniyle öğrenciler arasında ziyaret edilen bir bölge olduğu anlaşılmaktadır. Bahçelievler ve Tunalı bölgelerinin başlıca tercih edilme nedenlerinin ilgi çeken ve yaş aralığına hitap eden gece mekânlar1nın/aktivitelerinin olduğu görülmektedir. Yeni merkezi iş alanındaki tüm alt bölgelerde de ilgi çeken gece mekân/aktivitelerinin bulunması ve yaş aralığına hitap etmesi nedenleri olarak ortaya çıkmıştır. Bu yanıtlara ek olarak, araştırma öznesi olan öğrencilerin öğrenim gördüğü Çankaya Üniversitesi'nin Balgat Kampüsü'nün yakın çevresinde yer alan Çukurambar ve Söğütözü bölgesinin diğer tercih edilme nedenleri sırasıyla güvenlik (\%12.9) ve park yeri (\%9.2) sorunlarının olmaması olarak tespit edilmiştir. Bilkent bölgesinde, ek olarak, güvenlik sorunlarının (\%14.8) ve tekinsiz bireylerin (\%9.5) olmaması nedenleri gelmektedir. Ümitköy-Çayyolu bölgesi için ise temel tercih edilme gerekçelerini güvenlik (\%12.0) ve park yeri sorunu olmaması (\%7.4) ve çıkış/dönüş noktalarına yakın olması (\%7.4) nedenleri takip etmektedir. 
Tablo 6. Kent merkezlerinin tercih edilme nedenlerinin dağılımı

\begin{tabular}{|c|c|c|c|c|c|c|c|c|c|c|c|c|c|c|}
\hline \multirow[t]{2}{*}{$\begin{array}{l}\text { Bölgelerin tercih } \\
\text { edilme nedenleri }\end{array}$} & \multicolumn{2}{|c|}{$\begin{array}{l}\text { Kale - Ulus } \\
\text { bölgesi }\end{array}$} & \multicolumn{2}{|c|}{$\begin{array}{l}\text { Kızılay } \\
\text { bölgesi }\end{array}$} & \multicolumn{2}{|c|}{$\begin{array}{l}\text { B.evler } \\
\text { bölgesi }\end{array}$} & \multicolumn{2}{|c|}{$\begin{array}{l}\text { Tunalı } \\
\text { bölgesi }\end{array}$} & \multicolumn{2}{|c|}{$\begin{array}{l}\text { Ç.ambar- } \\
\text { Söğütözü } \\
\text { bölgesi }\end{array}$} & \multicolumn{2}{|c|}{$\begin{array}{l}\text { Bilkent } \\
\text { bölgesi }\end{array}$} & \multicolumn{2}{|c|}{$\begin{array}{l}\text { Ümitköy- } \\
\text { Çayyolu } \\
\text { bölgesi }\end{array}$} \\
\hline & $\mathrm{N}$ & $\%$ & $\mathrm{~N}$ & $\%$ & $\mathrm{~N}$ & $\%$ & $\mathrm{~N}$ & $\%$ & $\mathrm{~N}$ & $\%$ & $\mathrm{~N}$ & $\%$ & $\mathrm{~N}$ & $\%$ \\
\hline $\begin{array}{l}\text { İlgimi çeken } \\
\text { gece mekânlarının/ } \\
\text { aktivitelerinin olması }\end{array}$ & 13 & 16.7 & 63 & 16.1 & 102 & 18.1 & 105 & 21.9 & 98 & 15.2 & 53 & 15.7 & 85 & 19.7 \\
\hline $\begin{array}{l}\text { Güvenlik sorunları } \\
\text { olmaması }\end{array}$ & 3 & 3.8 & 10 & 2.6 & 46 & 8.2 & 46 & 9.6 & 83 & 12.9 & 50 & 14.8 & 52 & 12.0 \\
\hline $\begin{array}{l}\text { Park yeri sorunu } \\
\text { olmamasi }\end{array}$ & 2 & 2.6 & 4 & 1.0 & 6 & 1.1 & 10 & 2.1 & 59 & 9.2 & 29 & 8.6 & 32 & 7.4 \\
\hline $\begin{array}{l}\text { Çıış/Dönüş } \\
\text { noktama yakınlığı }\end{array}$ & 4 & 5.1 & 56 & 14.3 & 55 & 9.8 & 32 & 6.7 & 50 & 7.8 & 15 & 4.4 & 32 & 7.4 \\
\hline $\begin{array}{l}\text { Yeterli ulaşım aracı } \\
\text { olması }\end{array}$ & 13 & 16.7 & 83 & 21.2 & 68 & 12.1 & 30 & 6.3 & 38 & 5.9 & 7 & 2.1 & 13 & 3.0 \\
\hline $\begin{array}{l}\begin{array}{l}\text { Trafik sorunu } \\
\text { olmaması }\end{array} \\
\end{array}$ & 1 & 1.3 & 6 & 1.5 & 2 & 0.4 & 2 & 0.4 & 22 & 3.4 & 22 & 6.5 & 27 & 6.3 \\
\hline Gürültüsüz olması & 6 & 7.7 & 1 & 0.3 & 4 & 0.7 & 1 & 0.2 & 31 & 4.8 & 17 & 5.0 & 17 & 3.9 \\
\hline $\begin{array}{l}\text { Kalabalık, tercih } \\
\text { edilen bir yer olması }\end{array}$ & 6 & 7.7 & 32 & 8.2 & 51 & 9.1 & 59 & 12.3 & 34 & 5.3 & 13 & 3.8 & 19 & 4.4 \\
\hline Tenha olması & 3 & 3.8 & 0 & 0.0 & 2 & 0.4 & 1 & 0.2 & 14 & 2.2 & 9 & 2.7 & 9 & 2.1 \\
\hline $\begin{array}{l}\text { Benim yaş aralığıma } \\
\text { hitap etmesi }\end{array}$ & 5 & 6.4 & 41 & 10.5 & 97 & 17.2 & 90 & 18.8 & 83 & 12.9 & 52 & 15.4 & 56 & 13.0 \\
\hline $\begin{array}{l}\text { Altyapi sorunu } \\
\text { olmaması }\end{array}$ & 1 & 1.3 & 5 & 1.3 & 11 & 2.0 & 12 & 2.5 & 22 & 3.4 & 12 & 3.6 & 14 & 3.2 \\
\hline $\begin{array}{l}\text { Başıboş sokak hay- } \\
\text { vanların olmaması }\end{array}$ & 1 & 1.3 & 7 & 1.8 & 6 & 1.1 & 3 & 0.6 & 7 & 1.1 & 4 & 1.2 & 6 & 1.4 \\
\hline $\begin{array}{l}\text { Tekinsiz bireylerin } \\
\text { olmaması }\end{array}$ & 1 & 1.3 & 3 & 0.8 & 23 & 4.1 & 24 & 5.0 & 38 & 5.9 & 32 & 9.5 & 26 & 6.0 \\
\hline $\begin{array}{l}\text { Aydınlatma } \\
\text { sorunu olmaması }\end{array}$ & 3 & 3.8 & 19 & 4.9 & 22 & 3.9 & 23 & 4.8 & 27 & 4.2 & 13 & 3.8 & 16 & 3.7 \\
\hline $\begin{array}{l}\text { Çoğunlukla bütçeme } \\
\text { uygun mekânların ak- } \\
\text { tivitelerin bulunması }\end{array}$ & 9 & 11.5 & 58 & 14.8 & 67 & 11.9 & 41 & 8.5 & 34 & 5.3 & 7 & 2.1 & 25 & 5.8 \\
\hline Diğer & 7 & 9.0 & 3 & 0.8 & 1 & 0.2 & 1 & 0.2 & 3 & 0.5 & 3 & 0.9 & 3 & 0.7 \\
\hline Toplam & 78 & 100 & 391 & 100 & 563 & 100 & 480 & 100 & 643 & 100 & 338 & 100 & 432 & 100 \\
\hline
\end{tabular}

Kale ve Ulus kent merkezinin yeterli ulaşım aracı olması ve ilgi çeken mekânların olmasından dolayı Kızılay kent merkezinin ise yeterli ulaşım aracı olmasından dolayı tercih edildiği diğer kent merkezlerinin ise ilgi çeken mekânların yer almasından dolayı çoğunlukla tercih edildiği Şekil 4'de de gösterilmektedir. 


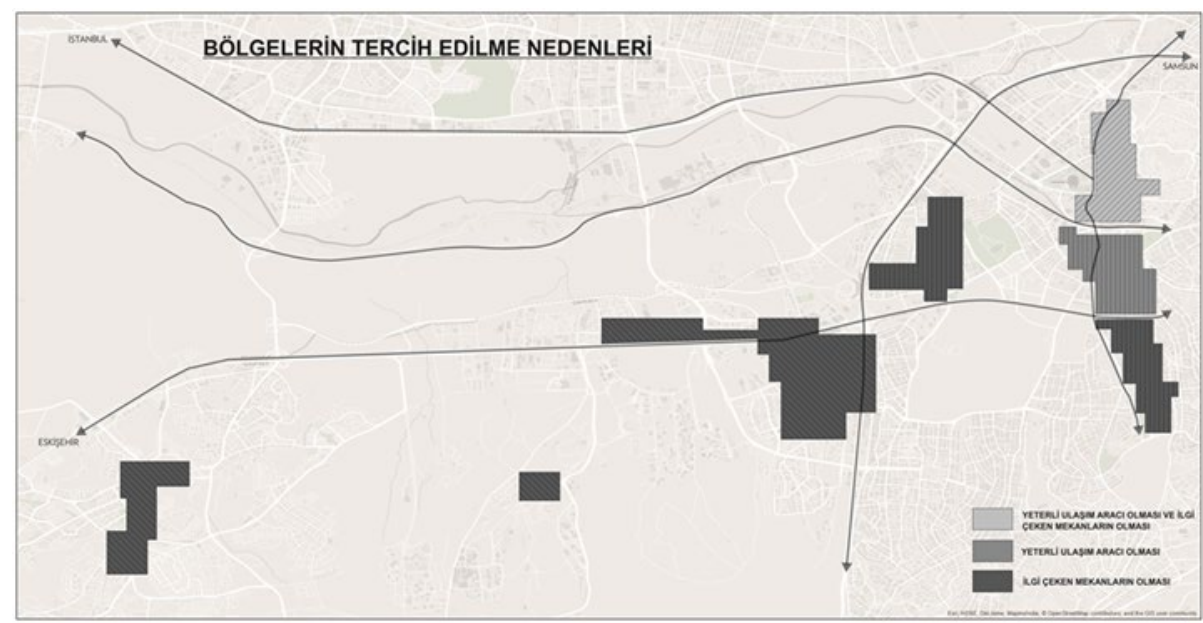

Şekil 4. Kent merkezlerinin tercih edilme nedenlerinin dağılım haritası

Öğrencilerin akşam ve gece saatlerinde merkezi alanları tercih etme sebeplerinin başında gelen "ilgi çekici ve yaş grubuma hitap eden aktivite ve mekânların bulunması" gerekçesini açmak üzere her bir merkezi alanda ne tür aktiviteler ve mekânlar için merkezi alanları ziyaret ettikleri sorulmuştur. Tablo 7'de kullanıcıların akşam saati aktivitelerinin merkezlere göre dağılımlarına yer verilmiştir. Buna göre, Kale ve Ulus bölgesinin sıklıkla tiyatroya gitmek amacıyla tercih edildiği, diğer tüm merkezi alanlarda ise en baskın aktivite mekânının kafe olduğu görülmektedir. Kızılay, Bahçelievler ve Tunalı Bölgelerinde bar, pub ve sinema kullanımlarının temel aktivite sahaları oldukları anlaşılmaktadır. Yeni iş merkezinde ise kafe mekânlarını restoran, sinema ve bar-pub kullanımları takip etmektedir. Aktivite mekânlarının bölgelere dağılımı incelendiğinde disko ve kulüp için Kızılay'ın tercih edildiği, nargileci, oyun salonu, maç yayını mekânları için en sık Çukurambar-Söğütözü bölgesinin, bar-pub için Bahçelievler ve Tunalı bölgelerinin, restoran için ise Çukurambar-Söğütözü ve Ümitköy-Çayyolu bölgelerinin seçildiği sonuçlarına ulaşılmıştır. 
Tablo 7. Bölgelerde gerçekleştirilen aktivite türlerinin dağılımı (\%)

\begin{tabular}{llllllll}
\hline Aktiviteler ve Bölgeler & $\begin{array}{l}\text { Kale - Ulus } \\
\text { bölgesi }\end{array}$ & $\begin{array}{l}\text { Kızılay } \\
\text { bölgesi }\end{array}$ & $\begin{array}{l}\text { B.evler } \\
\text { bölgesi }\end{array}$ & $\begin{array}{l}\text { Tunalı } \\
\text { bölgesi }\end{array}$ & $\begin{array}{l}\text { Ç.ambar - } \\
\text { Söğ̈̈tözü } \\
\text { bölgesi }\end{array}$ & $\begin{array}{l}\text { Bilkent } \\
\text { bölgesi }\end{array}$ & $\begin{array}{l}\text { Ümitköy- } \\
\text { Çayyolu } \\
\text { bölgesi }\end{array}$ \\
\hline Kafe & 0 & 25.9 & 25.2 & 21.8 & 28.7 & 28.9 & 25 \\
\hline Bar/Pub & 16.7 & 14.1 & 17.6 & 19.1 & 11 & 10.5 & 13.6 \\
\hline Restoran & 16.7 & 11.1 & 16 & 11.8 & 16.7 & 23.7 & 17.9 \\
\hline Sinema & 16.7 & 13.3 & 14.5 & 15.5 & 15.3 & 15.8 & 15 \\
\hline Tiyatro & 33.3 & 3.7 & 5.3 & 6.4 & 2.9 & 5.3 & 2.9 \\
\hline Disko/Kulüp & 17 & 6.7 & 1.5 & 4.5 & 1.4 & 5.3 & 5.7 \\
\hline Konser & 0 & 9.6 & 9.9 & 7.3 & 4.3 & 2.6 & 5.7 \\
\hline Sokak/Meydan/Park & 0 & 8.1 & 4.6 & 8.2 & 9.1 & 5.3 & 7.1 \\
\hline $\begin{array}{l}\text { Nargileci/Oyun } \\
\text { salonu }\end{array}$ & 0 & 4.4 & 2.3 & 1.8 & 5.3 & 2.6 & 5 \\
\hline Maç yayın & 0 & 1.5 & 3.1 & 2.7 & 4.3 & 0 & 0.7 \\
\hline $\begin{array}{l}\text { Opera/Bale/ } \\
\text { Klasik konser }\end{array}$ & 0 & 1.5 & 0 & 0.9 & 1 & 0 & 1.4 \\
\hline Toplam & 100 & 100 & 100 & 100 & 100 & 100 & 100 \\
\hline
\end{tabular}

Kent merkezlerinin gece saatlerindeki tercih edilme nedenlerinin yanı sıra, gençlerin merkezi alanları kullanmak istememe nedenleri sorgulanmış ve sonuçlar Tablo 8' de özetlenmiştir. Akşam ve gece saatlerinde kullanıcı sayısı bakımından yüksek oranda tercih edilmeyen bölge olan Kale ve Ulus bölgesi için temel gerekçeler güvenlik sorunlarının olması (\%19.7), tekinsiz bireylerin varlığı (\%15.3) ve ilgi çeken gece mekânlarını//etkinliklerin olmaması (\%14.7) şekilde sıralanabilir. Kentin planlı merkezi alanı için ortak tercih edilmeme nedeni park yeri sorunudur. Örneklemin \%52'sinin araç sahibi olduğu göz önüne alındığına bu merkezlerdeki park yeri sorununun gece saatlerinde tercih edilmeme gerekçesi doğurması anlaşılır bir argümandır. Her bir merkezi alana bakıldığında, K1zllay bölgesinin güvenlik sorunları (\%16.0) ve kalabalık olması (\%14.5) nedenleriyle tercih edilmediği görülmekte; Bahçelievler ve Tunalı bölgelerinin ise benzer şekilde kalabalık olması, trafik sıkışıklığı yaşanması, gürültülü olması nedenleriyle tercih edilmediği görülmektedir. Aynı zamanda birer yaşam çevresi olan planlı merkezdeki alt bölgelerin gece saatlerindeki kullanıcıları ve yaşayanlar açısından olumsuzluk oluşturduğu görülmektedir. Yeni iş merkezini oluşturan alt bölgelere bakıldığında, Balgat Kampüsü'nün yakın çevresinde yer alan Çukurambar-Söğütözü bölgesi için çoğunlukla pahalı mekânların bulunması (\%23.4), yeterli ulaşım aracının olmaması (\%11.9) ve ilgi çeken gece mekânlarının/etkinliklerinin bulunmaması (\%11.5) nedenleriyle tercih edilmediği anlaşılmaktadır. Bilkent ve Ümitköy-Çayyolu bölgelerinin tercih edilmeme nedenlerinin başında çıkış/dönüş noktalarına uzak olmaları gelmektedir; bunu her iki bölge için de çoğunlukla pahalı mekânların bulunması ve yeterli ulaşım aracı olmaması nedenleri izlemektedir. Kentin merkezi çekirdeğinden uzayarak batı ekseninde gelişen 
ve her biri merkezi iş alanı niteliği taşıyan bölgeler için gece saatlerindeki erişilebilirlik konusunun gençler için temel sorunlardan biri olduğu anlaşılmaktadır.

Tablo 8. Kent merkezlerinin tercih edilmeme nedenlerinin dağılımı

\begin{tabular}{|c|c|c|c|c|c|c|c|c|c|c|c|c|c|c|}
\hline \multirow[t]{2}{*}{$\begin{array}{l}\text { Bölgelerin tercih } \\
\text { edilme nedenleri }\end{array}$} & \multicolumn{2}{|c|}{$\begin{array}{l}\text { Kale - Ulus } \\
\text { bölgesi }\end{array}$} & \multicolumn{2}{|c|}{$\begin{array}{l}\text { Kızılay } \\
\text { bölgesi }\end{array}$} & \multicolumn{2}{|c|}{$\begin{array}{l}\text { B.evler } \\
\text { bölgesi }\end{array}$} & \multicolumn{2}{|c|}{$\begin{array}{l}\text { Tunalı } \\
\text { bölgesi }\end{array}$} & \multicolumn{2}{|c|}{$\begin{array}{l}\text { Ç.ambar- } \\
\text { Söğ̈utözü } \\
\text { bölgesi }\end{array}$} & \multicolumn{2}{|c|}{$\begin{array}{l}\text { Bilkent } \\
\text { bölgesi }\end{array}$} & \multicolumn{2}{|c|}{$\begin{array}{l}\text { Ümitköy- } \\
\text { Çayyolu } \\
\text { bölgesi }\end{array}$} \\
\hline & $\mathbf{N}$ & $\%$ & $\mathbf{N}$ & $\%$ & $\mathbf{N}$ & $\%$ & $\mathbf{N}$ & $\%$ & $\mathbf{N}$ & $\%$ & $\mathbf{N}$ & $\%$ & $\mathbf{N}$ & $\%$ \\
\hline $\begin{array}{l}\text { Bu alana gitme- } \\
\text { dim; fikrim yok. }\end{array}$ & 57 & 9.0 & 6 & 1.1 & 6 & 1.8 & 16 & 4.5 & 7 & 3.2 & 29 & 8.8 & 20 & 7.0 \\
\hline $\begin{array}{l}\text { İlgimi çeken gece } \\
\text { mekânlarının/ } \\
\text { aktivitelerinin } \\
\text { olmaması }\end{array}$ & 93 & 14.7 & 60 & 10.6 & 17 & 5.2 & 11 & 3.1 & 25 & 11.5 & 29 & 8.8 & 21 & 7.4 \\
\hline $\begin{array}{l}\text { Güvenlik } \\
\text { sorunları olması }\end{array}$ & 125 & 19.7 & 91 & 16.0 & 5 & 1.5 & 7 & 2.0 & 2 & 0.9 & 1 & 0.3 & 2 & 0.7 \\
\hline $\begin{array}{l}\text { Park yeri } \\
\text { sorunu olması }\end{array}$ & 47 & 7.4 & 102 & 18.0 & 86 & 26.1 & 71 & 20.1 & 11 & 5.0 & 8 & 2.4 & 7 & 2.5 \\
\hline $\begin{array}{l}\text { Çıkış/Dönüş nok- } \\
\text { tama uzak olması }\end{array}$ & 34 & 5.4 & 24 & 4.2 & 29 & 8.8 & 35 & 9.9 & 22 & 10.1 & 74 & 22.4 & 66 & 23.2 \\
\hline $\begin{array}{l}\text { Yeterli ulaşım aracı } \\
\text { olmaması }\end{array}$ & 11 & 1.7 & 10 & 1.8 & 11 & 3.3 & 22 & 6.2 & 26 & 11.9 & 55 & 16.6 & 39 & 13.7 \\
\hline Trafik sıkışıklığı & 24 & 3.8 & 62 & 10.9 & 50 & 15.2 & 46 & 13.0 & 12 & 5.5 & 10 & 3.0 & 10 & 3.5 \\
\hline Gürülttülü olması & 15 & 2.4 & 47 & 8.3 & 36 & 10.9 & 36 & 10.2 & 12 & 5.5 & 10 & 3.0 & 5 & 1.8 \\
\hline Kalabalık olması & 17 & 2.7 & 82 & 14.5 & 60 & 18.2 & 58 & 16.4 & 15 & 6.9 & 17 & 5.1 & 7 & 2.5 \\
\hline Tenha olması & 47 & 7.4 & 10 & 1.8 & 3 & 0.9 & 5 & 1.4 & 2 & 0.9 & 6 & 1.8 & 5 & 1.8 \\
\hline $\begin{array}{l}\text { Diğer yaş aralığına } \\
\text { hitap etmesi }\end{array}$ & 31 & 4.9 & 8 & 1.4 & 8 & 2.4 & 7 & 2.0 & 13 & 6.0 & 8 & 2.4 & 15 & 5.3 \\
\hline $\begin{array}{l}\text { Altyapı sorunu ol- } \\
\text { ması (Tuvalet, çöp) }\end{array}$ & 11 & 1.7 & 11 & 1.9 & 4 & 1.2 & 7 & 2.0 & 2 & 0.9 & 3 & 0.9 & 1 & 0.4 \\
\hline $\begin{array}{l}\text { Başıboş sokak hay- } \\
\text { vanları }\end{array}$ & 6 & 0.9 & 3 & 0.5 & 2 & 0.6 & 0 & 0.0 & 11 & 5.0 & 3 & 0.9 & 18 & 6.3 \\
\hline $\begin{array}{l}\text { Tekinsiz bireylerin } \\
\text { varlığı }\end{array}$ & 97 & 15.3 & 48 & 8.5 & 7 & 2.1 & 10 & 2.8 & 2 & 0.9 & 2 & 0.6 & 3 & 1.1 \\
\hline $\begin{array}{l}\text { Karanlık olması / } \\
\text { aydınlatma sorunu }\end{array}$ & 16 & 2.5 & 3 & 0.5 & 1 & 0.3 & 2 & 0.6 & 3 & 1.4 & 5 & 1.5 & 2 & 0.7 \\
\hline $\begin{array}{l}\text { Pahalı mekânların } \\
\text { bulunması }\end{array}$ & 2 & 0.3 & 0 & 0.0 & 4 & 1.2 & 20 & 5.6 & 51 & 23.4 & 70 & 21.1 & 64 & 22.5 \\
\hline Diğer & 0 & 0.0 & 0 & 0.0 & 1 & 0.3 & 1 & 0.3 & 2 & 0.9 & 1 & 0.3 & 0 & 0.0 \\
\hline TOPLAM & 633 & 100 & 567 & 100 & 330 & 100 & 354 & 100 & $\begin{array}{l}21 \\
8 \\
\end{array}$ & 100 & 331 & 100 & 285 & 100 \\
\hline
\end{tabular}

Şekil 5'de kentsel merkezi alanların akşam ve gece saatlerinde başlıca tercih edilmeme nedenlerinin dağılım haritası yer almaktadır. Bu haritada da Kale ve Ulus bölgesinin güvenlik sorunundan; Kızılay, Tunalı ve Bahçelievler kent merkezlerinin park yeri sorunundan; yeni iş merkezlerinden olan ÜmitköyÇayyolu ve Bilkent merkezlerinin erişilebilirlik ve Çukurambar-Söğütözü merkezinin ise pahalı mekânlarla şekillenmesinden dolayı tercih edilmediği görülmektedir. 


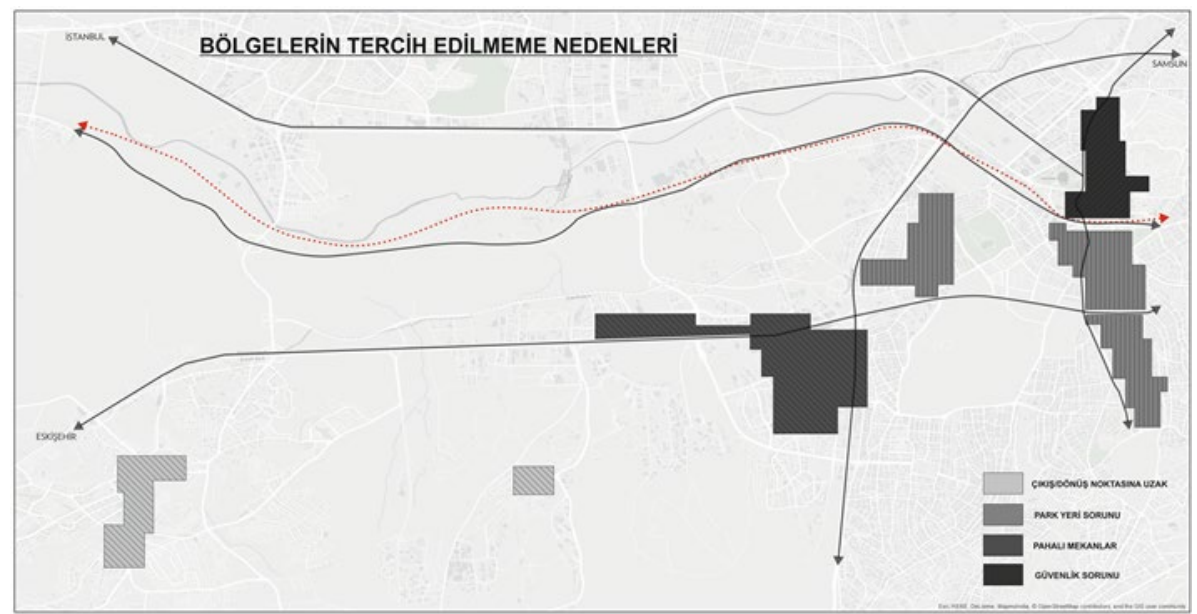

Şekil 5. Kent merkezlerinin tercih edilmeme nedenlerinin dağılım haritası

(Güngör, 2020)

\section{Tartışma}

Kentlerin hava karardıktan sonraki saatlerde nasıl kullanıldığı konusu uzun süredir kent planlamanın ve kamu politikalarının gündeminde yer almış ancak, Türkiye'de mekânsal planlara nasıl dahil edileceğine yönelik girişimler oldukça sınırlı bir kapsamda kalmıştır. Bu çalışma, gece saatlerinde kent merkezlerinin kullanımına nasıl devam edildiğini gösteren ilk adımlardan biri olup, gece planlamasına yönelik politika önerileri geliştirmeyi hedeflemektedir.

Kullanıcılar, gece saatlerinde erişim, aktivite ve mekânların çeşitliliği, güvenlik, dolaşım kolaylığı, temizlik gibi değişen koşullara göre kent merkezlerini deneyimlemeye devam etmektedir. Ancak, kullanıcıların kentin sunduğu bu olanaklara yaklaşımları ve kenti gece saatlerinde deneyimleri farklılaşmaktadır. Çalışma kent merkezlerinin gece saatlerinde tercih edilmesinin alanın sunduğu gece saati olanaklarına göre şekillendiği ve bunun da kullanıcı tercihleri arasında farklılaşmaya yol açtığı varsayımına dayanmaktadır. Ankara örneğinde incelenen gece zamanı kent merkezi kullanımı araştırmasında kentin farklı dinamiklere sahip merkezi alanlarına odaklanılmıştır. Nitelikleri ve hizmet sunumları açısından gündüz saatlerinde birbirinden farklılaşan kent merkezleri, benzer şekilde, gece saatlerinde de çeşitlenen kullanımlarla yaşamaya devam etmektedir. Kentin tarihi çekirdeğinden başlayarak zaman içinde gelişen ve yayılan merkezi alanları simgesel, ekonomik, sosyal, kültürel ve mekânsal olarak farklılaşan dinamiklere sahiptir. Bu durum, kullanıcıların tercihlerine yön verdiği gibi, kullanıcılar da merkezlerin biçimlenişinde önemli bir rol oynamaktadır. Bu çalışma ile gece saatlerinde de farklı nitelikler gösteren 
Ankara'nın merkezi alanlarının kullanıcılar tarafından nasıl algılandığı ve kullanıldığı konusuna odaklanılmıştır. Yazında, kenti gece saatlerinde ayakta tutan en geniş grubun gençler olduğu ve yine gençlerin gece zamanında tüketim ve eğlence mekânlarının kullanıcıları haline geldiği belirtilmektedir. Genç kullanıcıları temsil etmek üzere belirlenen bir örneklemle yürütülen bu çalışmada üniversite öğrencilerinin gece saatlerindeki kent merkezleri algiları ve kullanım tercihleri incelenmiştir. Bu alanlardaki deneyimlerin ve kullanıcı algısının farklılığından hareketle, her bir alana özgü geliştirilecek stratejilerle gece zamanının planlanmasının gerekliliğine vurgu yapılmaktadır.

Çalışmada temel olarak, gençlerin gece saatlerinde kentin merkezi alanlarına karşı farklılaşan bir tutum sergilediği gösterilmiştir. Buna göre, kentin planlı merkezi ve yeni iş koridoru gece saatlerinde daha sık tercih edilirken, özellikle geleneksel merkezin gençler tarafından yaygin olarak kullanılmadığı ortaya konulmuştur. Bu farklılaşma, kentin merkezi alanlarına yönelik özgün politikaların uygulanması gerektiğini anlatmaktadır.

Çalışmanın bulgularından hareketle ortaya çıkan ikinci sonuç, gece saatlerindeki kullanım farklılıklarının nedenlerinin de her bir merkezi alana göre değişiklik göstermesidir. Tarihi merkez erişim kolaylığı sunarken, planlı merkez gençlerin ilgisi çeken kullanımları barındırması, bütçelerine uygun mekânların ve aktivitelerin bulunması ve erişim kolaylığı nedeniyle cazip görünmektedir. Yeni iş koridorundaki merkezi alanlarda gece aktivitesi sunan mekânların bulunmasının yanı sıra güvenlik sorunlarının olmaması ve otopark yeterliliği nedenleriyle tercih edildikleri görülmektedir. Buna karşın, öğrencilerin gece saatlerinde dışarı çıma pratiklerinde karşılaştıkları sorunlar veya algılarından dolayı kent merkezini tercih etmeme eğilimleri de doğmaktadır. Geleneksel kent merkezini akşam ve gece saatlerinde tercih edilmeme sebeplerinin başında güvenlik sorununun geldiği ve gençler tarafından tekinsiz bireylerin yer aldığı, yan kesicilik ve hırsızlık olaylarının yaşandığı bir alan olarak algılandığı görülmektedir. Cumhuriyet döneminin hem eğlence hem de ticaret ve yönetim merkezi olan bölgenin, günümüzde gece saatlerinde tercih edilmeyerek sönümlendiği veya farklı gruplarca kullanıldığı çıkarımı ortaya atılabilir. Planlı merkez her ne kadar erişilebilir bulunsa da, özellikle araç sahiplerinin otopark sorunu yaşaması alanı tercih etmemelerinin temel gerekçesini oluşturmaktadır. Bir diğer konu ise genellikle gençlerin bütçelerine uygun mekânların ve aktivitelerin yer alması alanın farklı sosyo-ekonomik grupları çekememesi, gece hayatında da sosyal karmanın oluşamamasına ve bu durumda kentin ana merkezinde sosyo-zamansal ayrışmaya yol açma riski bulunmaktadır. Öte yandan, özel- 
likle konut alanlarının bulunduğu Bahçelievler ve Tunalı bölgeleri sunduğu cazip gece mekânlarının yanında kalabalıklık, sıkışıklık ve gürültü sorunlarını getirmesiyle eleştirilmektedir. Yeni iş koridorundaki merkezi alanlarda ise öğrencilerin pahalı bulduğu mekânların yer almasının gece saatlerinde vakit geçirmek için tercih edilmeme sebebi olduğu anlaşılmaktadır. Ek olarak, yeni gelişim alanındaki eğlence mekânı odaklarının çıkış veya varış noktalarına uzak olduğunu belirten özellikle araç sahibi olmayan kullanıcılar için caydırıcı olduğu anlaşılmıştır. Bu alanların sunduğu yüksek ücretli hizmet ve erişilebilirliğin zor olması araç sahibi olmayan ve düşük bütçeli gruba ev sahipliliği yapamadığını göstermekte ve gece saatlerinde sosyo-mekânsal ayrışmanın deseninin ortaya çıkmasına yol açmaktadır.

Ankara' da kentsel merkezi alanların gece zamanındaki durumunun bir kesitini ortaya koyan bu çalışmada merkezler arasındaki farklılıklar ve sosyomekânsal ayrışma önemli ölçüde okunmaktadır. Buradan hareketle, karar vericiler için gece saatlerindeki aktivitelerin tercih edilmesi üzerinden bir öneri seti sunulabilir. İlk olarak, kentin tarihi alanı gece saatlerinde üniversite öğrenimi görmekte olan gençlerin tercih etmediği, kendi yaş gruplarına hitap eden aktiviteleri bulamadıkları bir merkez niteliğindedir. Bu durum, merkezin farklı sosyal gruplarca kullanılması veya gece saatlerinde terk edilmesine neden olabilecek ve alanda sosyo-zamansal ve sosyo-mekânsal ayrışmanın oluşmasına yol açabilecektir. Bu ayrışmanın önüne geçmek üzere kentsel yenileme araçları ile tanımlanmış canlandırma ve rehabilitasyon programlarının uygulanması gerekmektedir. Kentin planlı çekirdeği olan Kızılay için ise gece zamanına yönelik politikaların güvenlik konusuna eğilmesi gerektiği ortaya çıkmıştır. Kızılay'ın güney ve batı eksenlerindeki uzantısı olan Bahçelievler ve Tunalı merkezi bölgelerinde konut, kamu, ticaret yapılarının bir arada yer alması bölgede gece saatlerinde de trafik sıkışıklığı ve gürültü problemlerinin yaşanmasına neden olmaktadır. Aynı zamanda otopark sıkıntısının yaşanması da araç sahibi kullanıcılar tarafından bölgelerin tercih edilmemesine yol açmaktadır. Bu merkezlerin kullanıciları toplu taşıma sistemlerine yönelmekte, ancak belli bir saatten sonra toplu taşıma hizmetleri azaldığından uzun süre dişarıda kalmak isteyenler için de bu bölgelerin cazibesi azalmaktadır. Büyük bir konut stokunu barındıran bu alanlar için gece aktivitelerinin yer alması çevre ve gürültü kirliliği sorunlarını alan sakinlerine de yüklemektedir. Ayrıca, alandaki sakinlerin artan fiyatlar ve değişen yaşam biçiminden dolayı bölgeden uzaklaşma sorununu doğurabileceği düşünülmektedir. Gece aktivitelerinin konut alanlarındaki dağılımına yönelik karma kullanımı düzenleyici mekânsal planlama kararlarına ek olarak kamu politikalarına gereksinim bulunmaktadır. Kentin batı 
koridorunda yer alan merkezi alanların yeterli ulaşım imkânı bulamaması nedeniyle araç sahibi kullanıcılarla ve yüksek fiyatlı gece aktivitelerine ev sahipliği yapması nedeniyle orta ve üst gelir gruplarıyla karakterize edildiği görülmekte, ortaya çıkan sosyo-mekânsal ayrışmanın giderilmesi için ulaşım esnekliği ve ekonomik çeşitlilik sunan aktivitelerin bir araya getirilmesi özendirilmelidir. Burada nitelikli kamusal mekânların oluşturulması sosyo-mekânsal ayrışmanın giderilmesinin önemli bir unsuru olarak göz önüne alınmalıdır.

Kuşkusuz, çalışmada sunulan öneriler, kullanıcıların gece aktiviteleri tercihlerini dikkate alan ve beraberinde oluşabilecek sorunları gözeterek mekânsal planlamaya girdi sağlayacak bir bakış açısı sunmaktadır. Elbette ki, kentsel merkezleri yalnızca gece aktivitelerini gözeten politikalarla şekillendirilemez. Ancak, yirmi dört-saatlik kentin oluşabilmesinin bir parçası olarak gece aktivitelerinin dağılımının bir kent planlama sorunsalı haline gelmesi ve kentin gündüz ve gece peyzajının birbirine tamamlar nitelikte çalışması gerekmektedir. Bunu yaparken, merkezi alanlarda çatışan konuların doğabileceği öngörülmelidir; bunların en başta konut kullanımlarının yoğun olduğu alanlarda görülebileceği göz önünde bulundurulmalıdır. Gece aktivitelerinin baskın olması durumunda, merkezi iş alanlarının gündüz saatlerinde işlevsizleşmesi sorununun doğabileceği de düşünülmelidir. 


\section{Extended Abstract}

\section{Youth's Preference on the Use of Urban Central Districts in the Evening and Nighttime Hours}

\author{
Ezgi Orhan \\ ORCID: 0000-0002-9124-7812
}

\author{
Merve Güngör \\ ORCID: 0000-0002-7305-2480
}

Planning the events taking place in the central parts of the city "after dark" supports the maintenance of urban vitality and livability. For this reason, it is important to ensure the development of nighttime spaces and their use by different groups of people. In Turkey, social, economic and spatial dimension of the nighttime is a fairly new area for local policy makers and planners, and studies on nighttime planning is still at its infancy. The aim of the article, which sets out from this gap, is to reveal the trends in the central business areas of the city by analyzing the preferences of young people for night use of urban centers.

This article departs from the argument that the spatial organization and character of night activities, which are shaped by the taste and demand of users, especially the young population, have an effective role in the development of the central business districts. Therefore, in order to reveal the nightscape of the urban central districts, an empirical research was conducted in Ankara, Turkey. In the study, the central parts of the city were grouped as the traditional center, the planned center and new development corridor allowing to reflect the planning history of the city. A sample of 250 university students were applied a face-to-face questionnaire to determine their nocturnal use of different central parts of Ankara.

It is revealed that young people showed differentiations in their night perception on the city centers hosting entertainment venues and various night activities. Users' perception on urban nightscape was questioned with respect to the variables of gender, the campus in which they studied, car ownership, length of their residence in Ankara, the type of residence in Ankara, their frequency of visit of centers at night, the length of their visit, the type of vehicle they use, returning time, and average expenditure. In addition to the user pro- 
file, it is showed that young people associated their preferences to the advantages and disadvantages offered by each central area regarding the night activities. Accordingly, Çukurambar-Söğütözü district was found as the most frequently visited district at night by respondents which was followed by planned center. However, the sample reported that the traditional city center was not a favorable location at evening and night hours. The reasons of their preferences in visiting the central districts were questioned. By analyzing nighttime preferences of young in city centers, it was showed that planned center of the city provides an accessible location and budget-friendly venues for young people. Besides, respondents explained the reasons of their preferences of the new development corridor through its offering on a more secure environment and more parking space than other districts. They associated their unwillingness to visit the traditional center with their perception of insecurity to the area. It is to be said that the traditional center that had been the entertainment, trade and administrative center of the Republican period seems to extinguish at night as a result of the preferences of today's youth. The already built-up central districts, i.e. Bahçelievler and Tunalı districts, were criticised by the problems of crowdedness, congestion and noise beside the advantages they offer such as the variety of attractive venues. Also, the new business corridor was found disadvantageous for students due the accessibility problems and the dominance of expensive venues. In this respect, drawing a section of the urban nightscape of Ankara, this study reveals the differences between the central districts and the socio-temporal separation in the city.

Departing from the results of the study, policy recommendations were developed for decision makers on urban central areas hosting differentiating night-time activities. Firstly, in order to avoid the socio-temporal and socio-spatial segregation among the districts, traditional center should be targeted in urban revitalization and rehabilitation programs. Secondly, the nightlife in planned central districts should be decided together with the residents that have to share the traffic, congestion, noise and contamination problems with visitors. Policy-makers should notify that such problems may lead to relocation of residents from their neighborhoods. Thirdly, the new business corridor that is characterised by middle and upper income groups should be supported by public transportation and activities allowing economic diversity. Here, the creation of qualified public spaces should be considered as an important element of eliminating the socio-spatial segregation. 


\section{Kaynakça/References}

Bayraktar, A. (2016). Başkent Ankara'da cumhuriyet sonrası yaşanan büyük değişim: Modern yaşam kurgusu ve modern mekânlar. Ankara Araştırmalan Dergisi, 4(1), 67-80.

Cattan, N., ve Vanolo, A. (2014). Gay and lesbian emotional geographies of clubbing: reflections from Paris and Turin. Gender, Place \& Culture, 21(9), 1158-1175.

Chatterton, P., ve Hollands, R. (2003). Urban nightscapes: Youth cultures, pleasure spaces and corporate power. Psychology Press.

Çağlak, U. ve Satır, M.E. (2012). Eğlence mekânları ve yeni medya: Mekânın görünümleri üzerine bir değerlendirme. Selçuk Üni. Sosyal Bil. Ens. Der., 2020(44), 317-326.

Günay, B. (2006). Ankara çekirdek alanının oluşumu ve 1990 Nazım Planı hakkında bir değerlendirme. (Der.) T. Şenyapıll, Cumhuriyet'in Ankarası, içinde (s.60-119), ODTU Yayıncilı: Ankara.

Güngör, M. (2020). Üniversite öğrencilerinin kentsel merkezi alanlari akşam ve gece saatlerinde kullanimi: Ankara kenti örneği, Yüksek Lisans Tezi, Çankaya Üniversitesi Fen Bilimleri Enstitüsü, Ankara.

Güzelsoy, S. (2008). İstanbul Kent Merkezi'nin Dönüşümü: Gelişme ve Planlama İkilemi. Yüksek Lisans Tezi, Mimar Sinan Güzel Sanatlar Üniversitesi: İstanbul.

Hannigan, J. (1998). Fantasy City: Pleasure and Profit in the Postmodern Metropolis. Routledge: London.

Hollands, R. G. (1996). From shipyards to nightclubs: Restructuring young adults' employment, household, and consumption identities in the North-East of England. Berkeley Journal of Sociology, 41, 41-66.

Liempt, I., Van Aalst, I., ve Schwanen, T. (2015). Introduction: Geographies of the urban night. Urban Studies, 52(3), 407-421.

Lovatt, A. ve O'Connor, J. (1995). Cities And The Night-Time Economy. Planning Practice and Research, 10(2), 127-134.

Matthew M. ve Chew (2009). Research on Chinese Nightlife Cultures and Night-Time Economies, Chinese Sociology \& Anthropology, 42(2), 3-21.

Oldenburg, R. (1989). The great good place: Café, coffee shops, community centers, beauty parlors, general stores, bars, hangouts, and how they get you through the day. Paragon House Publishers.

Önder, D. (2012). Sosyomekânsal Bir Tarih: Ankara Kentinde Eğlence- Dinlence Mekânlarının Değişen Biçimi ve Anlamı. 3. Kentsel ve Bölgesel Araştırmalar Sempozyumu Bildiriler Kitabı,içinde (s. 279-293), Matsa Basımevi: Ankara.

Roberts, M., ve Eldridge, A. (2009). Planning the night-time city. Routledge: Abingdon.

Rowe, D., Stevenson, D., Tomsen, S., Bavinton, N., ve Brass, K. (2008). The City After Dark Cultural Planning and Governance of the Night-time Economy in Parramatta. Western Sydney: Centre for Cultural Research.

Seijas, A. (2018). A guide to managing your. By Sound Diplomacy. 7 Aralık 2019 tarihinde https://www.sounddiplomacy.com/night-time-economy-guide adresinden erişilmiştir. 
Sumbas, A. (2013). Türk modernleşmesi'ni Ankara Palas üzerinden okumak: Doğu'dan Batı'ya açlan bir pencere. H.Ü. İktisadi ve İdari Bilimler Fakültesi Dergisi, 31(1), 171-198.

Tellan, D. (2016). Mekân, eğlence ve popüler kültür ilişkisini değerlendirmek. TRTakademi, 136-153.

Thomas, C. J., ve Bromley, R. (2000). City-centre revitalisation: Problems of fragmentation and fear in the evening and night-time city. Urban Studies, 37(8), 1403-1429. 